OPEN ACCESS

Edited by:

Mirella Dottori,

University of Wollongong, Australia

Reviewed by:

Ranran Zhang,

Rutgers, The State University of New Jersey, United States

Bang Manh Tran,

The University of Melbourne, Australia

*Correspondence:

Yan-Ru Lou

yanru_lou@fudan.edu.cn

Specialty section:

This article was submitted to

Stem Cell Research,

a section of the journal

Frontiers in Cell and Developmental

Biology

Received: 28 July 2021

Accepted: 08 September 2021

Published: 01 October 2021

Citation:

Chang M, Bogacheva MS and

Lou Y-R (2021) Challenges

for the Applications of Human

Pluripotent Stem Cell-Derived Liver

Organoids.

Front. Cell Dev. Biol. 9:748576.

doi: 10.3389/fcell.2021.748576

\section{Challenges for the Applications of Human Pluripotent Stem Cell-Derived Liver Organoids}

\author{
Mingyang Chang', Mariia S. Bogacheva ${ }^{2}$ and Yan-Ru Lou'* \\ 1 Department of Clinical Pharmacy and Drug Administration, School of Pharmacy, Fudan University, Shanghai, China, \\ ${ }^{2}$ Division of Pharmaceutical Biosciences, Faculty of Pharmacy, University of Helsinki, Helsinki, Finland
}

The current organoid culture systems allow pluripotent and adult stem cells to selforganize to form three-dimensional (3D) structures that provide a faithful recapitulation of the architecture and function of in vivo organs. In particular, human pluripotent stem cell-derived liver organoids (PSC-LOs) can be used in regenerative medicine and preclinical applications, such as disease modeling and drug discovery. New bioengineering tools, such as microfluidics, biomaterial scaffolds, and 3D bioprinting, are combined with organoid technologies to increase the efficiency of hepatic differentiation and enhance the functional maturity of human PSC-LOs by precise control of cellular microenvironment. Long-term stabilization of hepatocellular functions of in vitro liver organoids requires the combination of hepatic endodermal, endothelial, and mesenchymal cells. To improve the biological function and scalability of human PSCLOs, bioengineering methods have been used to identify diverse and zonal hepatocyte populations in liver organoids for capturing heterogeneous pathologies. Therefore, constructing engineered liver organoids generated from human PSCs will be an extremely versatile tool in in vitro disease models and regenerative medicine in future. In this review, we aim to discuss the recent advances in bioengineering technologies in liver organoid culture systems that provide a timely and necessary study to model disease pathology and support drug discovery in vitro and to generate cell therapy products for transplantation.

Keywords: human pluripotent stem cells, liver organoid, regenerative medicine, disease modeling, drug development

\section{INTRODUCTION}

An organoid is a self-assembled three-dimensional (3D) structure formed by stem/progenitor cells in vitro, which can reproduce many structures and functions of an organ (Lou and Leung, 2018). Organoids can be generated from pluripotent stem cells (PSCs), including embryonic stem cells (ESCs) and induced pluripotent stem cells (iPSCs), and tissue-specific adult stem cells. To date, various types of organoids have been generated to mimic tissues of heart, intestine, liver, lung, brain, etc. (Mansour et al., 2018; Miller et al., 2019; Serra et al., 2019; Wang S. et al., 2019; Rossi et al., 2021). Organoid technology represents a significant enhancement of the 3D culture system. The advantage of organoid cultures is that they are combined with bioengineering technology to mimic target organ structure and environment (Yin et al., 2016), and they contain cell types with in vivo 
properties suitable as development and disease models (Collins et al., 2019; Wörsdörfer et al., 2020; Ogoke et al., 2021). Despite the wide applications of organoids, tissue microenvironment, such as cell-cell and cell-matrix interactions, need to support complicated regulatory network, which is important to maintain the homeostasis of an organ. Biological engineering methods have enabled us to guide cell communication and cell behavior to analyze how organs work and to reconstruct the system, which are essential processes in organoid establishment.

Human liver is a structurally and functionally complex organ (Popper and Schaffner, 1957; Weiss et al., 1988), involving distinct cell types and microenvironment and possessing more than 500 functions. The liver consists of endodermderived hepatocytes (parenchymal cells) and cholangiocytes and mesoderm-derived sinusoidal endothelial cells, hepatic stellate cells, Kupffer cells, periportal fibroblasts, etc. The liver development requires self-organization of the cells, the process involving biochemical and biophysical cues for morphogenesis and coordinated gene activation/repression, leading to organogenesis (Koepsell et al., 2007; Tam and Loebel, 2007). Therefore, in terms of structural resemblance and functional generalization of the liver organ, liver organoids are superior to cells cultured in two-dimension (2D).

The term liver organoid (LO) refers to $3 \mathrm{D}$ multicellular spherical structure made of one or more liver cell types, for example, hepatocyte organoid refers to an organoid formed by hepatocytes. LOs with multiple cell types can better mimic the liver organ while LOs with single cell type are easier to form. LOs can be established from PSCs, fetal, or adult liver cells, and the latter two can be generated directly from human biopsy specimens (Hendriks et al., 2021). Like liver development in vivo, PSC-derived liver organoids (PSC-LOs) resemble the structure and functionality of the liver at certain developmental stage depending on the differentiation condition. The crucial problem of PSC-LOs is known to be immature characteristics. Therefore, optimized organoid engineering protocols are continuously being developed to terminally differentiate PSCs into hepatocyte-like organoids (Touboul et al., 2010; Takebe et al., 2017; Pettinato et al., 2019). Mun et al. (2021) claimed for the first time that treatment of human PSC-LOs with short-chain fatty acid mixture of acetate, propionate, and butyrate improved metabolic maturation which may help to accurately assess the CYP3A4dependent drug toxicity.

LOs are useful for a diverse range of applications, such as studying causes and processes of diseases, gene functions, and cell interaction with tissue environments (van Ineveld et al., 2020; Zhu et al., 2020; Brooks et al., 2021; Thompson and Takebe, 2021; Wang et al., 2021). For in vitro applications, LOs have great potential in screening drug hepatotoxicity and modeling liver diseases. One of the causes of high attrition rates is druginduced liver injury (DILI). In terms of human models of hepatotoxicity, Davidson and Khetani (2020) have developed a scalable culture of human LOs in 384-well plates, which are fully predictive of human DILI and facilitate high-throughput compound screening. For in vivo applications, LOs provide hope for cell therapy to treat end-stage liver diseases. However, LOs still face several limitations before they can be used in these applications. Current organoid systems are translationally disadvantaged by variability in self-organization, morphology, and function (Lou and Leung, 2018). Matrigel, used in most cases of organogenesis, still poses the limitation to in vivo applications of organoids (Ng et al., 2018; Klotz et al., 2019; Krüger et al., 2020). In this review, we aim to discuss the recent advances in bioengineering technologies in LO culture systems and how bioengineering methods can increase the value of LOs in fundamental research and translational research, such as drug development, precision medicine, and regenerative medicine.

\section{Types of Liver Organoids Adult Stem Cell-Derived Liver Organoids}

Organoid technology has been used to establish hepatic stem cell populations in vitro (Schneeberger et al., 2020). A standard adult stem cell-derived LO culture system is a highly potent platform for modeling adult liver from patients' tissue specimens (Schene et al., 2020). LOs can be established from single $\mathrm{EpCAM}^{+}$cholangiocytes and expanded for several months, while retaining key functional and molecule features after longterm expansion (Huch et al., 2015). It is well-known that adult primary hepatocytes do not replicate in vitro, but recent LO studies have allowed them to become highly proliferative, resembling proliferating hepatocytes upon partial hepatectomy or inflammation. Hu et al. (2018) have reported long-term culture of adult hepatocyte-derived organoids that consist of progenitors and differentiated hepatocytes. The researchers confirmed that these hepatocyte organoids were derived from albumin-positive hepatocytes rather than $\mathrm{EpCAM}^{+}$and SOX9 ${ }^{+}$ductal cells. In another study, researchers utilized a regenerative cytokine TNF $\alpha$ to establish long-term expansion of hepatocyte organoids from adult hepatocytes, which mimics inflammation-induced liver regeneration (Peng et al., 2018).

Adult stem cell-derived LOs can be expanded seemingly indefinitely, however, these organoids are derived from a single germ layer, i.e., endoderm, which have limited potential, for example, in modeling complicated liver diseases that involves endoderm- and mesoderm-derived cells. It is tempting to expect that appropriate conditions can facilitate co-culture with mesoderm-derived cells to form liver organoids with significant degree of cellular functionality and architectural complexity.

\section{Cancer Derived Liver Organoids}

The liver cancer cell line hepatoma G2 (HepG2) and patientderived tumor xenografts (PDTXs) have long been used as tumor models and have significantly contributed to drug discovery for cancer therapy. 2D immortalized cell lines can easily proliferate in vitro, but their gene expression characteristics are highly altered that cannot recapitulate the function of cell types in vivo. Generation of PDTXs is labor intensive and time consuming. On the other hand, the generation of patient-derived tumor organoids (PDTOs) is faster. PDTOs have heterogeneous genetic features and can completely simulate tumor characteristics in vivo. Thus, PDTOs have enormous potential for modeling human cancers (Kuo and Curtis, 2018; Muthuswamy, 2018) and have been increasingly used in drug development and clinics for personalized drug treatment. 
Broutier et al. (2017) have established primary cancer LOs that recapitulate parental tumors, even after long-term expansion in vitro. Diverse in vitro culture methods, such as bioengineering organoid, allow modeling of tumor heterogeneity or immunity. Cancer LO platform combined with the immune system, angiogenesis, and fibroblasts that retain tumor cell heterogeneity has become a cancer model for cancer microenvironment research and will unleash great potential in evaluating anticancer drug efficacy (Papapetrou, 2016; Pauli et al., 2017; Vlachogiannis et al., 2018).

\section{Human Pluripotent Stem Cell-Derived Liver Organoids}

The hepatic differentiation of human PSCs starts with definitive endoderm (DE) differentiation followed by the formation and expansion of hepatic progenitors and the formation and maturaton of fetal hepatocytes. The generation of PSC-LOs may be performed either partly in $3 \mathrm{D}$, for example, the formation of DE cells (Akbari et al., 2019), hepatic progenitors (Wang S. et al., 2019), or hepatocyte-like cells (Sgodda et al., 2017) in $2 \mathrm{D}$ condition followed by the transfer of obtained cells into $3 \mathrm{D}$ condition for the maturation, or completely in 3D from the beginning of the PSC stage (Guan et al., 2017). Hepatic endoderm cells can aggregate into 3D structures in certain conditions, particularly as a result of the activation of FGF and BMP signaling pathways (Takebe et al., 2013).

Human PSCs-LOs can contain single or multiple cell types, such as hepatocytes, cholangiocytes, and other non-parenchymal cells, which self-organize to form the structural units present in the liver. As a result, they are closely mimicking the complex structure and functionality of the liver.

Human PSC-LOs rely on the self-organizing ability of stem cells and progenitors to form organized structures for modeling developmental processes of liver organogenesis. To better control the differentiation processes and decrease heterogeneity, organoids should be designed to generate a specific liver region according to liver zonation. In vitro models mimicking liver zonation have been established by HepaRG cells and hepatocytes from neonatal rats (Ahn et al., 2019; Janani and Mandal, 2021).

\section{Liver Diseases}

Liver disease is one of the leading causes of death worldwide. According to the National Center for Health Statistics in the US, the morbidity of adults with diagnosed liver disease is $1.8 \%$ and is expected to continue in the next decades (National Center For Health Statistics, 2021). Common causes of chronic liver disease and cirrhosis are viruses, genetics, autoimmune disease, excessive alcohol use, and obesity. Acute liver failure, also known as fulminant hepatic failure, is caused by drugs or toxic chemicals. These are severe damage factors to the liver, and at a certain point in the progression of liver disease, the injury can become irreversible and lead to end-stage liver disease, liver failure, liver cancer, or death. Liver transplant is the only effective treatment for end-stage liver diseases. The number of patients on waiting lists well exceeds organ donation rates and therefore people have high expectation for human PSCderived liver cells as an alternative treatment. Earlier studies have demonstrated the feasibility of human PSC-derived liver cells as cell therapy (Takebe et al., 2017). Additionally, human PSC-LOs have potential as in vitro models in drug discovery and development.

\section{CHALLENGES FOR THE APPLICATIONS OF HUMAN PLURIPOTENT STEM CELL-DERIVED LIVER ORGANOIDS}

\section{Regenerative Medicine}

As human PSC-derived cells represent a substitute to cadaver and organ transplantation, human PSC-LOs provides an avenue toward cell therapy. By using improved organoid technology and transplantation techniques, transplanted human PSC-LOs could potentially integrate and grow in vivo into functional liver tissue to replace injured hepatocytes and non-parenchymal cells that are caused by liver diseases. Nevertheless, before human PSCLOs are suitable for regenerative treatment, many issues must first be solved.

\section{Xenogeniciy of Biomatrices}

In the process of organoid formation, one aspect is the induction of stem cell differentiation that requires a large number of growth factors or small molecules that are tissue-specific and can change signaling pathways for cell survival, migration, and proliferation. The other aspect is the formation of 3D tissue-like structures that rely on $3 \mathrm{D}$ cell culture environments. When building a 3D cell culture environment, it is necessary to consider extracellular cues influenced by the scaffold, the composition of extracellular matrix (ECM) proteins, and the stiffness of the matrix. Matrigel-based matrix is often used for the generation and culture of various PSC-derived and tissue-specific stem cell-derived organoids including liver (Mun et al., 2020), brain (Lancaster et al., 2013), kidney (Takasato et al., 2015), and intestine (Sugimoto and Sato, 2017). Matrigel provides scaffolding and signaling by forming basement membranes to support cell attachment and functionality, including organoid formation (Xu and Zeger, 2001). Ouchi et al. (2019) embedded human PSC-derived foregut spheroids into Matrigel to create LOs. The resultant LOs consist of hepatocytes, hepatic stellate cells, and Kupffer cells with specific polarity and more mature characteristics in comparison with fetal human hepatocytes. A simultaneous induction of DE and mesoderm cells on Matrigel is another approach resulting in the formation of LOs containing two cell types-hepatocytes and biliary cells (Wu et al., 2019). Although Matrigel has great potential to support the generation of LOs, it is a basement membrane extracted from the Engelbreth-Holm-Swarm mouse sarcoma (Orkin et al., 1977), which severely limits organoid application in clinical practice.

\section{Xeno-free biomatrices}

Efforts have recently been made in developing clinically acceptable matrices or biomaterials for LOs (Table 1). The first class is animal-derived matrix, such as collagen type I, decellularized matrix, and hyaluronic acid. Collagen type $I$ is the key component of the liver ECM that affects cell growth, viability, 
TABLE 1 | 3D cell culture systems for human LOs.

\begin{tabular}{|c|c|c|c|c|c|c|}
\hline $\begin{array}{l}\text { 3D cell culture } \\
\text { system }\end{array}$ & Xenogenicity & Type & Cell types in LOs & Aim & Limitation & References \\
\hline Matrigel & Mouse-derived & Natural & $\begin{array}{l}\text { Human iPSC-derived } \\
\text { hepatocyte-, stellate-, } \\
\text { and Kupffer-like cells }\end{array}$ & Fibrosis model & Clinically unacceptable & Ouchi et al., 2019 \\
\hline Matrigel & Mouse-derived & Natural & $\begin{array}{l}\text { Human iPSC-derived } \\
\text { hepatocytes and biliary } \\
\text { cells }\end{array}$ & $\begin{array}{l}\text { Hepatobiliary } \\
\text { organogenesis }\end{array}$ & Clinically unacceptable & Wu et al., 2019 \\
\hline Collagen hydrogel & Animal-derived & Natural & $\begin{array}{l}\text { Human iPSC-derived } \\
\text { hepatocyte-like cells }\end{array}$ & Hepatic maturation & & Gieseck et al., 2014 \\
\hline $\begin{array}{l}\text { Decellularized } \\
\text { matrix }\end{array}$ & $\begin{array}{l}\text { Porcine } \\
\text { intestine-derived }\end{array}$ & Natural & $\begin{array}{l}\text { Human liver duct cells } \\
\text { or fetal hepatocytes }\end{array}$ & Clinical applications & $\begin{array}{l}\text { Batch-to-batch } \\
\text { variation }\end{array}$ & Giobbe et al., 2019 \\
\hline Alginate capsules & Plant-derived & Natural & $\begin{array}{l}\text { PSC-derived } \\
\text { hepatocytes and } \\
\text { stromal cells }\end{array}$ & Functional engraftment & & Song et al., 2015 \\
\hline $\begin{array}{l}\text { Nanofibrillar } \\
\text { cellulose hydrogel }\end{array}$ & Plant-derived & Natural & Human adult liver cells & Clinical applications & Non-biodegradable & Krüger et al., 2020 \\
\hline $\begin{array}{l}\text { Colloidal crystal } \\
\text { scaffolds with } \\
\text { collagen type I }\end{array}$ & Partially animal-derived & Synthetic/natural & $\begin{array}{l}\text { Human iPSC-derived } \\
\text { hepatic progenitors }\end{array}$ & $\begin{array}{l}\text { Fully defined matrix for } \\
\text { clinical applications }\end{array}$ & & Ng et al., 2018 \\
\hline $\begin{array}{l}\text { Poly } \\
\text { isocyanopeptides } \\
\text { and laminin-111 }\end{array}$ & Not animal-derived & Synthetic/natural & Human adult liver cells & Clinical applications & & Ye et al., 2020 \\
\hline $\begin{array}{l}\text { Poly (ethylene } \\
\text { glycol) (PEG) } \\
\text { hydrogels }\end{array}$ & Not animal-derived & Synthetic & Human adult liver cells & $\begin{array}{l}\text { Chemically defined for } \\
\text { clinical applications }\end{array}$ & & Sorrentino et al., 2020 \\
\hline $\begin{array}{l}\text { Matrix-free } \\
\text { suspension }\end{array}$ & None & None & $\begin{array}{l}\text { Human ESC-derived } \\
\text { hepatocyte-like cells }\end{array}$ & Hepatic maturation & & Ogawa et al., 2013 \\
\hline $\begin{array}{l}\text { Matrix-free } \\
\text { suspension }\end{array}$ & None & None & $\begin{array}{l}\text { Human ESC- derived } \\
\text { hepatocyte-like cells }\end{array}$ & Large-scale expansion & & Sgodda et al., 2017 \\
\hline
\end{tabular}

differentiation, and overall tissue organization. As xenogeneic collagen and hyaluronic acid are clinically acceptable, they can be used as a scaffold for the generation of LOs. Mixing of iPSCderived hepatocyte-like cells with collagen solution followed by heating for the induction of vitellogenesis led to the generation of a 3D structure with an in vivo-like architecture (Gieseck et al., 2014). The transfer of clumps of $2 \mathrm{D}$ iPSC-derived hepatocyte-like cells into $3 \mathrm{D}$ collagen-based scaffold doubled the percentage of glycogen-synthesizing cells, increased the expression of mature hepatic genes, decreased the expression of fetal liver markers AFP and CYP3A7, and promoted the establishment of cell polarity. The long-term stable functionality of cells in 3D makes this model a promising tool for toxicity assessment. Moreover, this model is suitable for high-throughput screening studies (Gieseck et al., 2014).

Owing to its complex in vivo-like properties, decellularized matrix is used more often to support cell expansion and differentiation than any existing matrix components (Giobbe et al., 2019). After decades of research, especially in recent years, the need for complex forms of ECM has been clarified (Manou et al., 2019). So far, better results have been obtained using matrix extracts prepared by decellularizing cartilage and myocardium tissues (Schwarz et al., 2012; Oberwallner et al., 2014). Ott et al. (2008) have previously developed a technology for organ decellularization that uses a detergent for cell removal from the heart. Decellularized scaffold retains tissue-specific 3D architecture and vascular network. The decellularized scaffolds have a wide variety of applications in reconstruction of liver tissue or organ (Uygun et al., 2010; Baptista et al., 2011; Minami et al., 2019). The low immunogenicity makes decellularized matrix clinically applicable.

Rat decellularized liver scaffold has been used for the formation of human iPSC-derived hepatocyte grafts after differentiation of the iPSCs into hepatocytes in 2D culture. Recellularization of the scaffold with iPSC-derived hepatocytes led to the expression of CYP3A4 enzyme and secretion of albumin but in a lower amount than 2D iPSC-derived hepatocytes (Minami et al., 2019). Although the maturity of the recellularized iPSCs-derived grafts was not high enough and needs more study for the improvement of the protocol, the important outcome of this research is the demonstration of the suitability of the xenogeneic decellularized scaffold for human liver engineering. Effective engraftment and high induction of hepatocyte and cholangiocyte markers were reached in hepatic stem cells cultured and differentiated in the decellularized liver matrix (Wang et al., 2011), showing the potential of decellularized scaffold for liver bioengineering. Decellularized ECM promotes higher CYP enzyme activity in iPSC-derived hepatocytes compared with cells cultured in synthetic poly-l-lactic acid scaffold covered with collagen (Wang et al., 2016). 
Decellularized ECM in combination with a linear polysaccharide hyaluronic acid has been shown to support the tight junction formation and possessed a lower immune response compared to other natural hydrogels (Deegan et al., 2016). Immunotolerance is one of the advantages of decellularized ECM, allowing its use in transplantation. Hyaluronic acid is an important component of the natural ECM. It is easy to modify hyaluronic acid in vitro to adjust its stiffness and other physical parameters according to its intended application. Particularly, hepatocytes grown in the hyaluronic acid hydrogel in 3D condition possessed high viability and growth rate (Burdick and Prestwich, 2011).

It remains challenging to obtain scalable and well-controlled organoids due to the complex composition and batch-to-batch variability of human or animal-derived matrices. Therefore, some plant-based biomaterials have been developed. Alginate, a marine algae water-soluble polysaccharide copolymer, has been successfully used for 3D cell culture. Alginate hydrogels are biocompatible, non-immunogenic, and hydrophilic (Fedorovich et al., 2007). Song et al. (2015) differentiated iPSCs into hepatocyte-like cells in a $2 \mathrm{D}$ environment, then co-aggregated them with stromal cells in a matrix-free environment, and then encapsulated the generated $3 \mathrm{D}$ organoids in alginate capsules and transplanted them into mice. The transplanted organoids demonstrated high albumin and $\alpha$-antitrypsin secretion compared with primary human hepatocytes. Nanofibrillar cellulose hydrogel (also called cellulose nanofibril hydrogel, $\mathrm{CNF}$ ) is a plant-origin xeno-free, non-toxic, and biocompatible hydrogel that has been successfully implemented for the $3 \mathrm{D}$ culture of human PSCs (Lou et al., 2014). Recently, CNF hydrogel was used to generate human adult liver-derived LOs (Krüger et al., 2020). The CNF was used for LO expansion due to its mechanical properties. It also provides a supportive environment to induce LOs to functional hepatocyte-like cells. Thus, the CNF hydrogel presents a viable alternative to Matrigel for clinical use.

Unlike natural biomaterials mentioned above, synthetic scaffolds possess adjustable features and users can modify stiffness, swelling rate, etc., as well as modify the scaffold with functional groups. A well-defined composition of synthetic scaffolds provides reproducible results. $\mathrm{Ng}$ et al. (2018) used inverted colloidal crystal scaffolds with type I collagen coating for the maturation of iPSC-derived hepatic progenitors. They have proved that the morphological and transcriptomic features of those hepatic progenitors were reached and overrode the liver characteristics level of the spheroids cultured on Matrigel. Pore size was claimed as an important factor that allowed cells to form spheroids. They demonstrated that the most optimal pore diameter for this purpose is $140 \mu \mathrm{m}$. The appropriate ECM-mimicking coating was shown necessary for the cell attachment when the scaffold is formed from the biologically inert material.

Ye et al. (2020) have recently provided a novel hydrogel based on polyisocyanopeptides and recombinant human laminin111, which is promising for human adult liver-derived LO culture over at least 14 passages. Moreover, they have recently shown that the elasticity of tissue ECM is critical to many cell types. It is believed that ECM elasticity can help cells develop and function (Sorrentino et al., 2020). By adjusting the composition and elasticity of an artificial matrix, we can simulate the properties (e.g., elasticity, extensibility) of the target tissue through the composition of the ECM. This result is of great significance to the maintenance of cell viability and function, the establishment of disease models, and tissue repair and regeneration.

In summary, matrix-based culture condition needs to be further improved to exclude immunogenic and clinically unacceptable matrix and biomaterials, so as to be used for regenerative medicine and transplantation.

\section{Matrix-free systems}

Matrix-free or biomaterial-free 3D culture does not have any problems related to xenogeneic matrix and thus can be easily adapted for clinical applications. Ogawa et al. (2013) demonstrated that the maturation of hepatocytelike cells can be increased through the transferring of human ESC-derived hepatocyte-like cells to the matrix-free suspension environment. Another study also formed LOs by aggregating PSC-derived hepatocyte-like cells (Sgodda et al., 2017). In this case, hepatocytes aggregated into organoids within $12 \mathrm{~h}$. This protocol allows better control of the differentiation in $2 \mathrm{D}$, and subsequent transfer into $3 \mathrm{D}$ culture led to the continuation of the differentiation that was determined by the change of the expression pattern of maturation genes. The authors also demonstrated the importance of size control of the LOs, indicating that the increase in the size is associated with the decrease in the hepatic functions.

In conclusion, for applications in regenerative medicine, the major xenogenic materials used in PSC-LO generation are biomaterials, such as Matrigel, which should be replaced with clinically acceptable biomaterial or removed when using suspension culture system.

\section{Genetic and Epigenetic Instability}

The iPSC technology offers full of promise for cell therapy (Takahashi et al., 2007; Yu et al., 2007; Mandai et al., 2017). The differentiation of iPSCs can generate tissue-specific cells for transplantation, and can also apply to in vitro studies and drug development (Grskovic et al., 2011; Inoue and Yamanaka, 2011; Plummer et al., 2019). One of the most important safety issues particularly related to the in vivo applications of PSCderived cells are genetic and epigenetic instability, resulting in variations. These variations can occur at distinct levels, mainly during the generation and maintenance of iPSCs and the differentiation and expansion of iPSC-derived cells. The genetic and epigenetic variations or unstable chromosomes may change the characteristic of iPSCs and affect differentiation capacity (Nishizawa et al., 2016), yet the instability has not been fully elucidated.

\section{Variations introduced into induced pluripotent stem cells}

The variations may originate from the heterogeneous genetics of source cell population (Huang, 2009). Moreover, if some specific variations in source cells effectively promote reprogramming, these variations will be amplified in the derived iPSCs 
(Cahan and Daley, 2013; Kilpinen et al., 2017). Burrows et al. (2016) compared human iPSC lines from two somatic cell types of four donors in terms of DNA methylation and gene expression and found that genetic variation between donors, but not between cell types, is the main cause for the differences between iPSC lines. By studying 711 human iPSC lines, Kilpinen et al. (2017) have found that $5-46 \%$ of variations were originated from differences between individuals (Cahan and Daley, 2013).

In addition, reprogramming protocols may introduce new variations by increasing mutations. Integrative vectors, such as lentivirus and retrovirus, can randomly integrate into the genome of iPSCs to interrupt endogenous gene expression and reactivate transgenes to lead to tumorigenesis, whereas non-integrating vectors, such as Sendai virus, adenovirus, and adeno-associated virus, induce transient expression of transcription factors. A whole exome sequencing study identified mutations in human iPSCs, of which $75 \%$ occurred during reprogramming process (Ji et al., 2012). Although the exact reason for mutagenesis was not identified in the study, retrovirus used in reprogramming could be one of the drivers. On the contrary, a later study compared three reprogramming methods, namely retrovirus, Sendai virus, and synthetic mRNA and found that the number of genetic variants identified by whole genome sequencing was moderate and did not differ between reprogramming methods (Bhutani et al., 2016). The authors concluded that reprogramming was unlikely to make human iPSCs unacceptable in cell therapy. Nonetheless, non-integrative vectors are recommended in clinical applications.

Like ESCs, iPSCs maintenance may introduce genetic or epigenetic alterations into cells. During iPSC culture, there were genetic variations among different passages or among different populations (Mayshar et al., 2010; Amps et al., 2011). These studies found that the level of overexpressed genes increased with the increased passage number and in some case, normal iPSCs at lower passage number exhibited gains in some chromosomes. Genetic and epigenetic variations preexisting in source cells or being introduced during reprogramming are subjected to selection in prolonged culture (Liang and Zhang, 2013). A highresolution single nucleotide polymorphism genotyping study has found that duplications of oncogenes tend to accumulate during prolonged passaging of human iPSCs (Laurent et al., 2011). An unbiased study using clonal culture has identified oxidative stress as the trigger for mutation accumulation during passaging and showed that the mutation rate in human iPSCs was lower than that in human intestinal and liver stem cells (Kuijk et al., 2020).

\section{Variations introduced into induced pluripotent stem cells-derived cells}

Genetic and epigenetic instability introduced during the differentiation of human PSCs has not been well investigated. A study using human parthenogenetic stem cells has accessed instability during a serial round of differentiation and reprogramming, i.e., differentiating parthenogenetic stem cells into parthenogenetic mesenchymal stem cells via the formation of embryoid body and reprogramming parthenogenetic mesenchymal stem cells into iPSCs using retrovirus-mediated delivery of OCT4, SOX2, KLF4, and c-Myc (Vassena et al., 2012). When comparing the firstround parthenogenetic mesenchymal stem cells with the second-round parthenogenetic mesenchymal stem cells by microarray analysis, the authors found more than 3,000 differentially expressed genes and concluded that these differences were introduced during reprogramming, though no evidence was provided to show the differences appeared during reprogramming, not during differentiation. Nonetheless, this study draws our attention that genetic and epigenetic instability should be examined throughout the process of reprogramming and differentiation to ensure safe cell therapy in regenerative medicine.

\section{Impact of genomic instability and coping strategies}

Many researchers have proven that different lines of iPSCs have diverse differentiation and developmental capability (Polo et al., 2010; Tsuji et al., 2010; Boulting et al., 2011; Kim et al., 2011; Liang and Zhang, 2013). This diversity is caused by cell of origin or genetic and epigenetic variations in iPSCs. Some of these variations may result in potential abnormalities in iPSC differentiation and induction, and thereby causing phenotypic changes and functional deficiencies, which pose risks in their in vivo applications as well as problems in disease modeling and drug development (Mekhoubad et al., 2012).

There are some coping strategies to reduce the iPSC variability, such as reducing the causes of variations in source cells and optimizing reprogramming methods and culture conditions. First, the preexisting mutations in source cells vary with the cell of origin. Ultraviolet-induced somatic mutations in skin fibroblasts were found in fibroblast-derived human iPSCs (D'Antonio et al., 2018). For this reason, hematopoietic stem cells show advantages over skin fibroblasts as a safe cell source (Wang K. et al., 2019). Second, reprogramming method should be carefully selected regarding integration, genomic instability, and tumorigenesis issues. Third, it is necessary to acquire enough cell numbers of iPSCs for differentiation studies and applications. In light of this purpose, genetic and epigenetic variations in iPSCs should be detected and monitored throughout passages (Martins-Taylor et al., 2011). Assou et al. (2020) have developed a test which can potentially detect more than $90 \%$ of human PSC recurrent genetic abnormalities from long-term culture and can be used to routinely screen genomic integrity in human PSCs. The test was established based on a large dataset of reported genetic and epigenetic abnormalities and uses droplet digital PCR technology which greatly simplifies the regular and systematic hPSC monitoring. In addition, it would be ideal to set up a bank of human iPSC and ESC lines, in which each line is maintained as a homogeneous and genetically stable population. To set up a transgene-free human iPSC bank enabling high-throughput generation and rapid expansion to meet industrial and clinical demands, Valamehr et al. (2014) have established a platform using small molecule pathway inhibitors in feeder-free culture condition. Further studies should focus on clarifying the genetic and epigenomic stability during the in vitro differentiation process, such as using chemically defined reagents to reduce variability and optimal 
oxygen condition, for the safe application of iPSCs-derived cells in regenerative medicine.

\section{Genome Editing}

Genome editing can be used to add, remove, or edit DNA of cellular genome to alter the characteristics of a cell or an organism, and it has the potential to both improve our understanding of human genetics and cure genetic diseases (Hou et al., 2013; Ran et al., 2015). The most used tool of genome editing is the RNA-guided CRISPR-Cas9 nuclease system that has emerged in recent years representing a system that is easy to design, highly specific, efficient, and suitable for high-throughput and multiplexed gene editing.

Since the establishment of human iPSCs, researchers had hoped to use patient's own iPSC-derived cells in regenerative medicine. However, there are four problems in autologous iPSCbased cell therapy: (1) the process of establishing autologous cell therapy is complex, time-consuming, and costly. This expensive treatment is difficult to promote and attract pharmaceutical companies to develop. (2) Autologous cell therapy is difficult to standardize. Quality control faces great challenges. (3) Autologous cell therapy cannot treat acute diseases, such as acute liver failure. (4) In the process of differentiation, the immunogenicity of autologous iPSCs will change, and the generated cells may not be immunotolerant as reported earlier (Zhao et al., 2015). On the contrary, allogeneic cells are easier to be standardized as a treatment, and can be mass produced into off-the-shelf products. However, immune rejection in allogeneic cell transplantation remains to be overcome. HLA matching iPSC lines have been established for allogeneic cell transplantation (Okita et al., 2011; Taylor et al., 2012). In recent years, scientists have established several methods to overcome the immune rejection of allogeneic PSCs. For example, CRISPR-Cas9-mediated destruction of HLA gene enhanced the immune compatibility of iPSCs (Hong et al., 2017; Xu et al., 2019; Lee et al., 2020). These studies about allogeneic human PSC-derived cells without immune responses as cell therapy open a new avenue toward regenerative medicine.

Allogeneic PSC-LO-induced immune rejection is primarily mediated by T cells. Strategies to regulate T cell costimulatory and inhibitory pathways can prevent immune rejection. A study using monoclonal antibodies to block $\mathrm{T}$ cell costimulation has shown immune tolerance of human ESC-derived pancreatic endoderm cells in mice (Szot et al., 2015). However, this strategy has a potential risk for cancer and infection.

Despite the obvious advantages that gene-edited iPSCbased cell therapy has, challenges like off-target, mutagenesis, tumorigenesis, and ethical debate may still exist. One of the major causes of the off-target effects of the CRISPR system is the continusly expressed Cas9 proteins in cells (Fu et al., 2013). Random integration resulted from offtarget effects can potentially develop insertional mutagenesis and subsequent tumorigenesis of transplanted cells. Thus, in order to reduce the off-target effects caused by Cas9 overexpression, strategies, such as decreasing the amount of undesirable DNA cleavage or suppressing the activity of
Cas9 protein, have been suggested (Nuñez et al., 2016). The use of a high-fidelity Cas9 variant is another strategy to reduce off-target events (Kleinstiver et al., 2016). We recently developed a Cas9 mRNA-based CRISPR genome editing method to efficiently edit human PSCs (Leung et al., 2020). We show that Cas9 existed in cells in a short period time. Like Cas9 ribonucleoprotein, our method can produce cells without foreign gene integration and thus can be easily translated into clinical applications. Thus, gene-edited PSCs together with organoid technology provide more opportunities in regenerative medicine.

\section{Large-Scale Expansion for Transplantation}

For future therapeutic applications of human PSC-derived liver cells, the number of cells required for each transplantation will be quite large, about one tenth of the liver mass which is approximately $10^{9}$ cells (Sharma et al., 2011). An earlier strategy was to expand human PSCs, and more recently researchers have found some ways to expand differentiating PSCs at certain developmental stages, such as endodermal cells using defined growth factors (Raju et al., 2017) and hepatoblasts by combining growth factors and small molecules (Zhang et al., 2015). These expanding hepatoblasts maintain phenotypes during long-term culture and can differentiate into mature hepatocytes and bile duct cells. The aim was to generate a source for cell therapy of liver diseases.

Organoid technology has recently been used to expand various types of cells in vitro. Wang S. et al. (2019) developed a differentiation cocktail medium for the differentiation of human ESCs into LOs with high expansion ability. Hepatic progenitors derived in 2D culture conditions were embedded in Matrigel and treated with a unique combination of B27, EGF, Wnt3A, Forskolin, N2, Nicotinamide, N-acetylcysteine, R-spondin, Gastrin, and A83-01 compound. This approach allowed longterm subculture of the resultant organoids (up to 20 passages) that remained stable after freezing-thawing procedures and mass-scale production of cells which is necessary for industrial applications. Another study showed that self-aggregated PSC spheroids formed in agarose microplates can differentiate in suspension into 3D liver tissue whose phenotype was stable for over 1 year without detectable tumorigenic activity after transplantation (Rashidi et al., 2018). The ability of the longterm culture of human PSC-LOs that remain their functional activity is one of the main advantages over primary human hepatocyte-derived organoids due to the limited supply of primary human liver tissue from healthy or diseased liver donors. Other researchers have generated LOs from human PSC-derived endoderm cells in 2 weeks and expanded them in Matrigel for more than 16 months without loss of differentiation capacity (Akbari et al., 2019). LOs spontaneously formed from 2D culture of differentiating human PSCs were expanded in Matrigel for 1 year while maintaining their karyotype and phenotype (Mun et al., 2020).

In summary, great efforts have been made to expand differentiating cells for large-scale production. However, the use of Matrigel must be replaced by a xeno-free matrix or biomaterial to meet clinical requirements. For regenerative 
medicine, expansion in suspension culture (Rashidi et al., 2018) seems superior than Matrigel culture.

\section{Transplantation and in vivo Engraftment}

Cell transplantation has potential for end-stage liver diseases (Tsuchida et al., 2020). Human PSC-LOs as a new source for cell transplantation is innovative but still at the preclinical stage. During the process of transplantation, the homing and survival of transplanted cells are major factors determining the success of transplantation. At present, there are no standard protocols defining the differentiation status of transplanted cells (fetal stage or mature stage), cell formulation (single cell suspension, organoid suspension, or biomaterial-based construct), transplantation site (systematic, orthotopic, or ectopic), and delivery technique (injection, infusion, or implantation).

The most commonly used method to deliver liver cells or LOs is injection, which involves intraportal injection, intravenous infusion, intramuscular injection, or intrasplenic injection. Intrasplenic or portal venous infusion can hardly control engraftment efficiency and avoid ectopic engraftment because transplanted cells first enter the blood circulation before reaching the liver. A recent preclinical study in pigs has reported that the ligation of the patent ductus venosus before portal venous infusion can inhibit extrahepatic translocation (Tsuchida et al., 2020). In intrasplenic transplantation, more than $70 \%$ transplanted cells are rapidly removed by resident immune cells (Gupta et al., 1999). An earlier study has found that the disruption of sinusoidal endothelium can facilitate the integration of transplanted cells into the liver (Gupta et al., 1999). Rashidi et al. (2018) transplanted human PSC-LOs in two ways, intraperitoneal injection and subcutaneous implantation with the aid of a polycaprolactone scaffold. Both methods improved the liver functions of diseased recipient mice, but the authors did not compare these two methods, only suggesting that ectopic implantation is less invasive. Tsuchida et al. (2019) recently reported that human iPSC-LO transplantation via the portal vein had good retention of organoids in the liver, whereas single cells of LOs translocated to the lung. Some studies have found that immature cells can further become mature once transplanted in vivo (Takebe et al., 2013), but there is still no solid evidence on the differentiation status of transplanted cells for the best functional engraftment while avoiding tumorigenesis of immature cells.

As an alternative to liver organ transplantation for liver failure, liver cells or LOs could directly implanted to the liver orthotopically. Nagamoto et al. (2016) have implanted a cell sheet composed of human iPSC-derived hepatocytes onto the liver surface of recipient mice with acute liver injury induced by $\mathrm{CCl}_{4}$. The orthotopic cell sheet transplantation exhibited better cell retention than intrasplenic injection, and thus had increased engraftment rate and efficacy. The authors also pointed out that a large number of cells can be transplanted using the cell sheet technology. To deliver LOs by the cell sheet technology, LOs need to be dissociated into single cells and then cultured in $2 \mathrm{D}$ to form a cell sheet. However, dissociation of LOs will disrupt tissue structure and may be incompatible with LO technology.
Despite many innovative transplantation methods, the low engraftment efficiency might be due to poor integration of human iPSC-derived cells to the local environment or the lack of vasculature in LOs. To evaluation transplantation and engraftment efficiency, we need non-invasive in vivo cell tracking methods (see the section below) (Tsuchida et al., 2020).

\section{In vivo Cell Tracking}

Real-time monitor of transplanted cells or organoids in vivo is necessary to study the fate of transplanted cells and evaluate engraftment during preclinical studies (Watson et al., 2014; Jung et al., 2018; Hsia et al., 2021). Ideally a reporter with highly sensitive 3D tomography is needed to non-invasively measure the engraftment of transplanted hepatic cells. Noninvasive measurement allows short, long-term, and repeated monitoring transplanted cells in vivo. The signal of an ideal reporter needs to last long and have resolution in certain depth to reach internal organs and at micrometer scale to localize cells. A study showed that human sodium iodide symporter (hNIS) can serve as such a reporter and can utilize radiotracers already available for clinical use to enable positron emission tomography or single photon emission computed tomography (Ashmore-Harris et al., 2019). In this study, human iPSC-derived immature hepatocytes were transduced with lentivirus containing dual-mode radionuclidefluorescence hNIS-mGFP reporter gene followed by further differentiation in vitro and transplantation in vivo. The signal of hNIS-mGFP reporter was stable and indicating the transplanted cells precisely homing to the liver, but the signal became undetectable 1 week later due to cell death in the in vivo environment.

Another in vivo tracing technology is Raman spectroscopybased modality that can mine data, such as proteomic and chemogenomic data. Coherent Raman scattering (CRS) microscopy is a high-speed vibrational imaging system that can visualize the chemical content of a living specimen. The major technique in CRS is coherent anti-Stokes Raman scattering (CARS) (Reintjes et al., 1982). With technical advances on hyperspectral CARS microscopy, researchers have provided many innovation studies on organoids. Pope et al. (2021) have investigated a complex multicellular system of LOs by using correlative two-photon fluorescence and hyperspectral CARS microscopy. Their most interesting finding is that organoids could be maintained alive under hyperspectral CARS measurements. In addition, they have established a method for label-free identification of chemically distinct subpopulations, which can be used to analyze and validate the quality of clinical cell transplantation. These studies emphasize the future of quantitative hyperspectral CARS microscopy as an empowering technology in regenerative medicine, showing the way to novel possibilities for non-invasive disease diagnosis.

In conclusion, to develop human PSC-LOs as a therapeutic product, safety, efficacy, and controllable quality must be fulfilled. Safety consideration includes genetic and epigenetic stability, non-xenogenicity, immune tolerance, and non-tumorigenesis. Efficacy is influenced by PSC-LO quality and delivery method. It still remains unclear on the effect of human PSC-LOs 
transplanted into the liver. Non-invasive in vivo cell tracking methods can help evaluate engraftment efficiency and cell fate.

\section{Disease Modeling and Drug Development}

Organoid technology is a powerful tool for the study of human diseases. LOs generated from patient-derived or genomeedited PSCs have the ability to model liver diseases, to screen drug candidates, and to test their toxicity. Liver is the main organ for drug metabolism and transport. It is also the main target organ of drug toxicity. An adverse drug reaction Peng et al. (2018) is an undesirable side effect of a drug and is classified as dose-dependent or idiosyncratic drug-induced damage. Historically, toxicology research has relied on animal models to characterize the toxicity of new compounds. However, animal models are not perfect systems for human toxicity, and it can only predict $50 \%$ of DILI in humans. Thus, human toxicity prediction models are urgently needed. Primary adult human hepatocytes are the "gold standard" for evaluating drug metabolism and toxicity. However, due to their limited availability and proliferation capacity, alternative in vitro models are needed. Human PSCs represents an unlimited cell source for all the cell types in human body and are expected to generate in vitro models for drug discovery and development (Lin et al., 2021). The applications of human PSC-derived liver cells include liver disease modeling, drug metabolism, and hepatotoxicity study. As mentioned in see section "Introduction," PSC-LOs show superior structural and functional advantages over 2D cultured PSC-derived liver cells. Guan et al. (2017) estabilished a disease model of JAG1 mutations based on human iPSC-LOs with bile duct-like structures. They adopted iPSC-based organoid system and genome editing technology to show the effect of mutations on human genetic diseases. For disease modeling and drug development, a number of challenges related to human PSC-LOs remain to be overcome. The major challenge of human PSC-LOs is immaturity of hepatocytes derived from current differentiation protocols (Lynch et al., 2019). Heterogeneity is another problem related to organoid technology in general (Lou and Leung, 2018), which reduces reproducibility of drug screening and testing. Building PSC-LOs with multiple cell types to mimic liver tissue complexity is another goal, which is particularly necessary when modeling liver diseases involving several cell types or studying DILI as hepatocyte damage is caused not only by direct toxic effect of drugs but also by indirect effect of nonparenchymal cell response.

\section{Immaturity}

Mature PSC-LO models should show basic liver functions and tissue environmental characteristics. The studies focusing on liver development have contributed to establishing PSC induction methods and mimicking the environment for fetal liver cell development and growth. Liver matures during perinatal period. However, due to the limited knowledge on perinatal human liver development, the immaturity of human PSC-LOs still remains an unsolved problem. This problem hinders their applications in disease modeling and drug development. Currently, the differentiation of hepatic progenitors is mediated by HGF, oncostatin M (Prodanov et al., 2016), and dexamethasone, but the resultant hepatocytes exhibit fetal liver features (Baxter et al., 2015), such as the expression of fetal marker alpha-fetoprotein (Lucendo-Villarin et al., 2020) and lower activity of CYP3A4 than primary hepatocytes (Lee et al., 2021).

In recent years, researchers have improved the hepatic maturation of human PSC-LOs by using different factors and small molecules. According to the changes in liver microenvironment at postnatal stage, researchers have found that microbial short-chain fatty acids could improve the metabolic functions of human PSC-LOs (Mun et al., 2021). Wu et al. (2019) have firstly established functional hepatobiliary organoids from human iPSCs. 25\% of mTeSRTM culture medium was replaced with RPMI-1640/B27 minus insulin at differentiation stages to induce hepatic and biliary codifferentiation, then $10 \%$ cholesterol $^{+}$MIX was added to promote maturation. Cholesterol ${ }^{+}$MIX is a preparation from Chinese medicine products, mainly comprised of cholesterol and other small molecules.

In addition, the role of non-parenchymal cells in liver maturation has also drawn attention. Asai et al. (2017) observed that iPSC-derived hepatic endoderm cells directly interacted with human umbilical vein endothelial cells (HUVECs) and mesenchymal stem cells during liver organoid morphogenesis. At the same time, HUVECs might also exert paracrine effects, such as secreting HGF, to promote hepatocyte differentiation. Another study shows that non-parenchymal cells, namely mesenchymal stromal cells and endothelial cells, improved the hepatic maturation of human PSC-LOs by decreasing TGF- $\beta$ and Wnt signaling pathways (Goulart et al., 2019).

ECM plays an important role in cell differentiation and organogenesis and may improve hepatic maturation of PSC-LOs. Zahmatkesh et al. (2021) efficiently improved hepatic maturation of LOs by mixing microparticles made of decellularized liver matrix with human PSC-derived endoderm cells, mesenchymal stromal cells, and HUVECs.

In conclusion, researchers in the past few years have made efforts to improve hepatic maturation of human PSC-LOs by applying small molecules found in the liver microenvironment during postnatal stage, incorporating non-parenchymal cells, and utilizing ECM components or bioengineering techniques (Table 2). The measurements indicating liver maturity vary a lot among different studies, from synthetic functions to metabolic functions. In some studies, the measurements were not compared with the primary adult human hepatocytes, and thus it is uncertain how mature these LOs are and whether they can be a valid model in disease modeling and drug development. The liver mature features should be selectively measured according to the intended applications of human PSC-LOs. We believe that with the better understanding of in vivo liver maturation, we will be able to generate PSC-LOs mature enough for drug screening and toxicity testing.

\section{Heterogeneity}

Heterogeneity refers to cellular, morphological, and functional non-uniformity of PSC-LOs. Heterogeneity during multi-step 
TABLE 2 | Strategies for improving maturity of human PSC-LOs.

\begin{tabular}{|c|c|c|c|c|c|c|}
\hline Strategies & Cell types & Key methods & $\begin{array}{l}\text { Representative } \\
\text { maturation } \\
\text { measures }\end{array}$ & Model & Comparison & References \\
\hline \multirow[t]{2}{*}{ Soluble factors } & $\begin{array}{l}\text { iPSC-derived } \\
\text { hepatocytes }\end{array}$ & $\begin{array}{l}\text { Acetate, } \\
\text { propionate, and } \\
\text { butyrate } \\
\text { combination in } \\
\text { hepatic medium } \\
\text { and differentiation } \\
\text { medium }\end{array}$ & $\begin{array}{l}\text { Increased CYP3A4 } \\
\text { activity and ALB } \\
\text { secretion }\end{array}$ & $\begin{array}{l}\text { Drug-induced liver } \\
\text { injury }\end{array}$ & $\begin{array}{l}\text { iPSC-LOs were } \\
\text { less sensitive than } \\
\text { PHHs to } \\
\text { troglitazone- } \\
\text { induced toxicity, } \\
\text { but HepG2 was not } \\
\text { sensitive. }\end{array}$ & Mun et al., 2021 \\
\hline & $\begin{array}{l}\text { iPSC-derived } \\
\text { hepatocyte- and } \\
\text { cholangiocyte-like } \\
\text { cells }\end{array}$ & $\begin{array}{l}25 \% \text { mTeSR in } \\
\text { endoderm medium } \\
\text { and } 10 \% \\
\text { cholesterol+ MIX } \\
\text { (Chinese medicine) } \\
\text { to maturation } \\
\text { medium }\end{array}$ & $\begin{array}{l}\text { Bile duct structure } \\
\text { and production and } \\
\text { transport of bile } \\
\text { acids }\end{array}$ & $\begin{array}{l}\text { Hepatobiliary } \\
\text { organogenesis }\end{array}$ & $\begin{array}{l}\text { The maturity of } \\
\text { iPSC-LOs was } \\
\text { between fetal liver } \\
\text { and adult liver. }\end{array}$ & Wu et al., 2019 \\
\hline \multirow[t]{2}{*}{ Co-induction } & $\begin{array}{l}\text { PSC-derived } \\
\text { hepatocytes and } \\
\text { cholangiocytes }\end{array}$ & $\begin{array}{l}\text { Hepatic endoderm } \\
\text { spheroids were } \\
\text { differentiated into } \\
\text { hepatoblast } \\
\text { spheroids, which } \\
\text { were dissociated } \\
\text { and seeded in an } \\
\text { ultra-low } \\
\text { attachment plate to } \\
\text { form LOs. }\end{array}$ & $\begin{array}{l}\text { Functional bile } \\
\text { canaliculi system }\end{array}$ & NASH model & $\begin{array}{l}\text { Free fatty } \\
\text { acid-treated } \\
\text { PSC-LOs showed } \\
\text { similar gene } \\
\text { expression } \\
\text { signatures to NASH } \\
\text { patients. }\end{array}$ & Ramli et al., 2020 \\
\hline & $\begin{array}{l}\text { Healthy and } \\
\text { Wolman diseased } \\
\text { PSC-derived } \\
\text { hepatocytes-, } \\
\text { stellate-, and } \\
\text { Kupffer-like cells }\end{array}$ & $\begin{array}{l}\text { PSC spheroids } \\
\text { embedded in } \\
\text { Matrigel were } \\
\text { stepwise } \\
\text { differentiated into } \\
\text { LOs. }\end{array}$ & $\begin{array}{l}\text { LOs can be } \\
\text { induced by free } \\
\text { fatty acid to have } \\
\text { inflammatory and } \\
\text { fibrotic responses. } \\
\text { All cell types in LOs } \\
\text { are functional. }\end{array}$ & $\begin{array}{l}\text { NASH/Fibrosis } \\
\text { model; Wolman LO } \\
\text { model }\end{array}$ & $\begin{array}{l}\text { Wolman LOs } \\
\text { exhibited more } \\
\text { aggressive fibrosis } \\
\text { phenotypes than } \\
\text { Wolman disease } \\
\text { patients. }\end{array}$ & Ouchi et al., 2019 \\
\hline \multirow[t]{3}{*}{ Co-culture } & $\begin{array}{l}\text { iPSC-derived } \\
\text { hepatocytes, } \\
\text { HUVECs, and } \\
\text { MSCs }\end{array}$ & $\begin{array}{l}\text { iPSC-derived } \\
\text { hepatic endoderm, } \\
\text { HUVECs, and } \\
\text { MSCs } \\
\text { self-organized into } \\
\text { 3D liver buds (LBs). }\end{array}$ & $\begin{array}{l}\text { Vascularized and } \\
\text { functional human } \\
\text { liver }\end{array}$ & $\begin{array}{l}\text { Regenerative } \\
\text { medicine }\end{array}$ & $\begin{array}{l}\text { iPSC-LBs } \\
\text { produced higher } \\
\text { levels of albumin } \\
\text { than human adult } \\
\text { hepatocytes in vivo. }\end{array}$ & Takebe et al., 2013 \\
\hline & $\begin{array}{l}\text { iPSC-derived } \\
\text { hepatocyte-like } \\
\text { cells, HUVECs, and } \\
\text { MSCs }\end{array}$ & $\begin{array}{l}\text { Hepatic-specified } \\
\text { endoderm } \\
\text { co-cultured with } \\
\text { HUVECs and } \\
\text { MSCs without } \\
\text { cell-cell contact. }\end{array}$ & $\begin{array}{l}\text { After no cell-cell } \\
\text { contact co-culture, } \\
\text { hepatocyte-like } \\
\text { cells had polarity } \\
\text { and bile acid } \\
\text { transport structure. }\end{array}$ & & $\begin{array}{l}\text { Some genes were } \\
\text { not upregulated } \\
\text { when compared } \\
\text { with primary } \\
\text { hepatocytes. }\end{array}$ & Asai et al., 2017 \\
\hline & $\begin{array}{l}\text { ¡PSC-derived } \\
\text { hepatocyte-, } \\
\text { endothelial-, and } \\
\text { MSC-like cells, } \\
\text { dental pulp- } \\
\text { derived-MSCs, and } \\
\text { human aortic } \\
\text { endothelial cells }\end{array}$ & $\begin{array}{l}\text { Five different cell } \\
\text { types were mixed } \\
\text { to generate four } \\
\text { organoid groups. }\end{array}$ & $\begin{array}{l}\text { The greatest } \\
\text { difference between } \\
\text { four groups is the } \\
\text { expression of } \\
\text { phase I and phase } \\
\text { II enzymes. }\end{array}$ & & $\begin{array}{l}\text { Both iPSC-derived } \\
\text { non-parenchymal } \\
\text { cells and adult } \\
\text { non-parenchymal } \\
\text { cells improved } \\
\text { hepatic functions } \\
\text { by mediating Wnt } \\
\text { and TGF- } \beta \\
\text { pathways. No } \\
\text { comparison with } \\
\text { primary } \\
\text { hepatocytes was } \\
\text { shown. }\end{array}$ & Goulart et al., 2019 \\
\hline
\end{tabular}

(Continued) 
TABLE 2 | (Continued)

\begin{tabular}{|c|c|c|c|c|c|c|}
\hline Strategies & Cell types & Key methods & $\begin{array}{l}\text { Representative } \\
\text { maturation } \\
\text { measures }\end{array}$ & Model & Comparison & References \\
\hline \multirow[t]{3}{*}{$\begin{array}{l}\text { Biomaterials and } \\
\text { bioengineering }\end{array}$} & $\begin{array}{l}\text { PSC-derived } \\
\text { hepatocyte-like } \\
\text { cells, HUVECs, and } \\
\text { UC-MSCs }\end{array}$ & $\begin{array}{l}\text { PSC-derived } \\
\text { hepatic endoderm, } \\
\text { HUVECs, and } \\
\text { MSCs were mixed } \\
\text { with liver } \\
\text { decellularized } \\
\text { matrix-derived } \\
\text { microparticles to } \\
\text { form LOs }\end{array}$ & $\begin{array}{l}\text { Microparticles } \\
\text { improved the } \\
\text { maturation and } \\
\text { metabolic capacity } \\
\text { of PSC-derived } \\
\text { hepatocytes. }\end{array}$ & Transplantation & $\begin{array}{l}\text { No comparison } \\
\text { with primary } \\
\text { hepatocytes was } \\
\text { shown. }\end{array}$ & $\begin{array}{l}\text { Zahmatkesh et al., } \\
2021\end{array}$ \\
\hline & $\begin{array}{l}\text { iPSC-derived } \\
\text { hepatocytes and } \\
\text { iPSC-derived } \\
\text { endothelial cells }\end{array}$ & $\begin{array}{l}\text { Hepatocytes and } \\
\text { endothelial cells } \\
\text { were encapsulated } \\
\text { in separate } \\
\text { domains of fibers } \\
\text { containing chitin, } \\
\text { alginate, galactose, } \\
\text { and collagen. }\end{array}$ & $\begin{array}{l}\text { Integration with } \\
\text { host vasculature } \\
\text { in vivo }\end{array}$ & $\begin{array}{l}\text { Liver tissue } \\
\text { engineering }\end{array}$ & $\begin{array}{l}\text { No comparison } \\
\text { with primary } \\
\text { hepatocytes was } \\
\text { shown. }\end{array}$ & Du et al., 2014 \\
\hline & $\begin{array}{l}\text { PSC-derived } \\
\text { hepatoblasts }\end{array}$ & $\begin{array}{l}\text { Hepatoblasts } \\
\text { seeded in } 500-\mu m \\
\text { diameter microwells } \\
\text { to form uniformly } \\
\text { sized } \\
\text { hepatocyte-like cell } \\
\text { (HLC) spheroids }\end{array}$ & $\begin{array}{l}\text { HLC spheroids had } \\
\text { sensitivity to various } \\
\text { hepatotoxicants }\end{array}$ & Drug hepatotoxicity & $\begin{array}{l}\text { Eight of the fifteen } \\
\text { compounds } \\
\text { showed higher } \\
\text { cytotoxic activity to } \\
\text { HLC spheroids } \\
\text { when compared } \\
\text { with primary } \\
\text { hepatocytes }\end{array}$ & Lee et al., 2021 \\
\hline
\end{tabular}

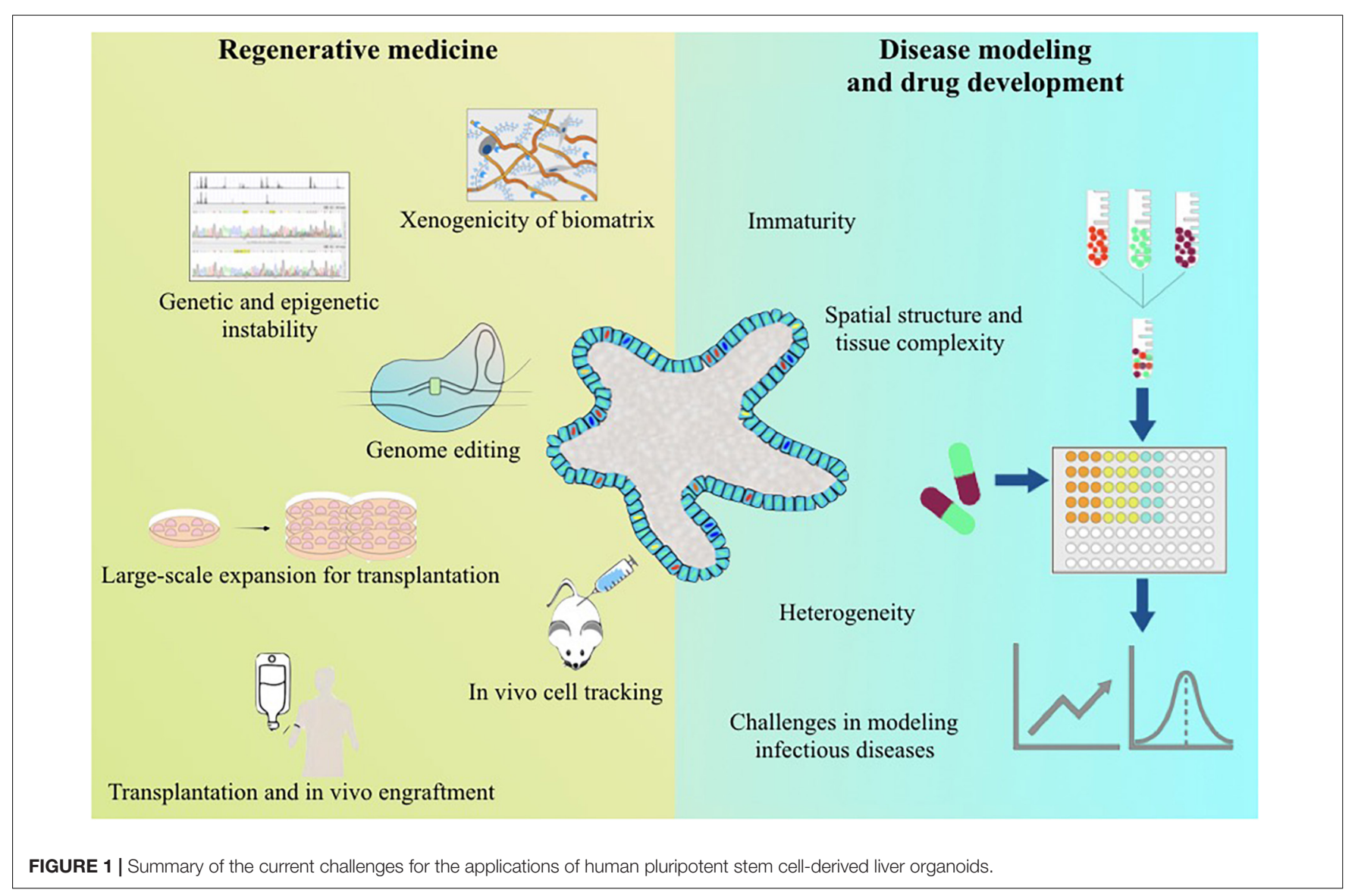


stem cell differentiation is a common problem and becomes even more problematic at the maturation stage of PSC differentiation into LOs. In disease modeling and drug testing, LO heterogeneity can decrease reproducibility of screens and tests. To overcome this issue, researchers have fabricated microwells to control spheroid size and uniformity (Takebe et al., 2017). Silicone microwells were recently used to generate uniform hepatocyte spheroids from human PSCs (Lee et al., 2021). These spheroids were more sensitive to liver toxins than 2D hepatocytes in image-based testing. Another study using agarose microplates also generated uniformly sized liver spheres containing human PSC-derived hepatic progenitors, hepatic stellate cells, and endothelial cells (Lucendo-Villarin et al., 2020). By utilizing automated platform, the researchers showed reduced variation and increased throughput. $3 \mathrm{D}$ bioprinting is a technology that uses thin layers of the cells and other components arranged on top of each other to form a complex biological structure. Because of the tools for the precise control of the process of tissue generation, and, therefore, the ability to create complex tissue patterns, $3 \mathrm{D}$ bioprinting has become a promising technology for transplantation, fundamental and applicable research. The most known bioprinting methods are laser pulses, extrusion, and inkjet (Kryou et al., 2019). One of the issues of 3D bioprinting for today is promoting the vascularization of a printed organ because organoids often fail to recapitulate the functionality of primary hepatocytes in the absence of vascularization. This can be solved by integrating microfluidics into bioprinting. Another issue is the stress to cells generated by $3 \mathrm{D}$ bioprinting tools (Faulkner-Jones et al., 2015).

\section{Spatial Structure and Tissue Complexity}

The majority of studies have focused on the generation of hepatocyte-like cells. However, the liver consists of multiple cell types, and for the better replication of liver structure, many recent projects have developed protocols that can produce LOs consisting of different liver cell types. A pioneer study generated $3 \mathrm{D}$ human liver buds by combining human iPSC-derived hepatic endoderm cells, mesenchymal stem cells, and HUVECs (Takebe et al., 2013). The hepatic functions of the generated liver buds were assessed both in vitro and after transplantation in mice with a liver failure model. Interestingly, interactions between multiple germ layer derivatives not only increased organoid complexity but also improved functionality. In vivo transplantation showed a spatial pattern expressed by these liver buds and reversed drug-induced lethal liver failure (Takebe et al., 2013, 2017). However, the organoid structure did not fully recapitulate the spatial organization of the liver, and the spatial structure also varies among organoids. Other studies also demonstrated that the combination of hepatocytes with non-parenchymal cells provided signaling interactions between cells that positively affected hepatic functions (Du et al., 2014).

Recently, Ramli et al. (2020) embedded single posterior foregut cells derived from human PSCs in Matrigel to form hepatic endoderm spheroids. Further treatment with BMP4, BMP7, and FGF7 resulted in the formation of hepatoblasts spheroids. Then, the dissociated hepatoblast spheroids were seeded into 96-well plates to form hepatic organoids consisting of hepatocytes and biliary cells with bile canaliculi. These two-cell type LOs were used in the study of nonalcoholic steatohepatitis (NASH) (Ganesh et al., 2019). Ouchi et al. (2019) took a different approach to generate multicellular LOs for the study of steatohepatitis. They first established foregut organoids from PSCs, which consisted of both endoderm and mesoderm derivatives. The foregut organoids were further differentiated into LOs composed of hepatocytes, stellate cells, and Kupffer cells. These LOs exhibited the feature of steatohepatitis when stimulated by free fatty acids. Diseased PSC-LOs were shown to be suitable for studying individualized therapy of human liver fibrosis.

Metabolic zonation is a unique feature of the liver. Liver zonation is regulated by oxygen gradient (Kietzmann, 2017), Wnt/ $\beta$-catenin signaling (Planas-Paz et al., 2016), and other pathways. Liver zonation makes liver structure highly complex and spatially heterogenous and also makes in vitro LO generation more challenging. To our knowledge, the current technology has not been able to generate PSC-LOs mimicking a specific liver metabolic zone. This could be a future research direction to obtain LOs with desired metabolic functions for certain studies. For example, NASH affects lipid zonation and causes cell damage in the pericentral region (Hall et al., 2017). Thus, PSC-LOs representing the pericentral region would be useful in modeling NASH. Oxygen and lipid gradient created by a microfluidic chip was used to study the progress of NASH in rat primary hepatocytes (Bulutoglu et al., 2019). This microfluidic device could be integrated with human PSC-LOs consisting multiple cell types to study intercellular crosstalk during the development of NASH. Ahn et al. (2019) developed a channel system in which HepaRG cells were grown under a concentration gradient of CHIR99021, an inducer of Wnt/ $\beta$-catenin pathway. This gradient created hepatic zonal environment that made HepaRG cells respond to toxic drugs differently, cells in the zone-3 region showing sensitivity to hepatotoxic drugs. It is known that ECM composition exhibits zone-dependent distribution. By adjusting ECM proportion on silk scaffold, researchers have created a hepatic zonation model that was tested with rat hepatocytes (Janani and Mandal, 2021). These are interesting models worth exploiting with human PSC-LOs to test zonal toxicity of drugs.

\section{Challenges in Modeling Infectious Diseases}

Due to species-dependent features of many human hepatotropic pathogens, human cells in vitro or in humanized chimeric animals are the only valid models to study pathogen infection and to develop therapies. Various models based on $2 \mathrm{D}$ or $3 \mathrm{D}$ cultured human primary hepatocytes, immortalized hepatic cells, and human PSC-derived hepatocytes either alone or combined with non-parenchymal cells have been established (Gural et al., 2018; Arez et al., 2021).

Earlies studies have shown the infection and replication of hepatitis $\mathrm{C}$ virus (HCV) in human PSC-derived hepatocytes, though these cells were not fully mature as evidenced by the expression of fetal liver markers (Roelandt et al., 2012; Schwartz et al., 2012). By closely examining HCV infection during differentiation, Wu et al. (2012) have found that undifferentiated 
human PSCs and DE cells were not permissive for HCV infection, but hepatic progenitors were readily infected with HCV. These studies present the application value of human PSC-derived hepatocytes in modeling HCV infection despite their unsatisfying maturity. Additionaly, when using iPSCs from patients with genetic diseases, this model can be used to study how genetic alteration affects $\mathrm{HCV}$ infection. Because 3D models can mimic the complexicity of the liver tissue, they show advantages in recapitulating some liver functions that $2 \mathrm{D}$ models cannot. However, to our knowledge, human PSC-LOs have not been used in the study of HCV-host interactions.

Primary adult human hepatocytes are the only host cell type for hepatitis B virus (HBV) infection in vivo, and thus they are the gold-standard for studying HBV-host interactions (Galle et al., 1994). An earlier study showed that HBV entered differentiated and polarized hepatocytes via basolateral membrane (Schulze et al., 2012). Sodium taurocholate cotransporting polypeptide (NTCP), mediating most of the $\mathrm{Na}^{+}$-dependent uptake of bile salts in the liver (Stieger, 2011) and being expressed on the basolateral membrane of highly differentiated hepatocytes, has been identified as a receptor for HBV (Yan et al., 2012). Because primary adult human hepatocytes were not able to maintain and expand in long-term culture, improved cell culture systems have been established to study HBV-host interactions in vitro. A micropatterned coculture of primary hepatocytes with stromal cells has shown support for HBV infection and enabled to study long-term HBV-host interactions (Shlomai et al., 2014). With this system, the authors have found variations of HBV infection among different donors. To study such variations in an isogenic background, the authors used human iPSC-derived hepatocytes and found that HBV infection occurred in fully differentiated hepatocytes, not in cells at earlier stages of differentiation. The maturation of hepatocytes in PSC-LOs requires assistance of their interactions with non-parenchymal cells (Si-Tayeb et al., 2010). Therefore, reconstruction of these interactions might be a feasible approach to promoting the modeling of infectious disease development. To better understand the life cycle of HBV and to develop effective anti-HBV drugs, Nie et al. (2018) have established a HBV infection model generated from human iPSC-LOs containing PSC-derived hepatocytes, mesenchymal stem cells, and HUVECs in a 3D microwell system. This infection model could support long-term replication of $\mathrm{HBV}$ and at the same time exhibit phenotypic alterations in hepatic functions and ultrastructure. Human iPSC-LO may still have some characteristics different from adult hepatocytes, which limits the modeling of authentic infection.

Malaria, caused by Plasmodium protozoan parasites, is another infectious disease related to liver. Careful examination of Plasmodium infection in differentiating human PSCs has

\section{REFERENCES}

Ahn, J., Ahn, J.-H., Yoon, S., Nam, Y. S., Son, M.-Y., and Oh, J.-H. (2019). Human three-dimensional in vitro model of hepatic zonation to predict zonal hepatotoxicity. J. Biol. Eng. 13, 1-15. doi: 10.1186/s13036-019-0148-5

Akbari, S., Sevinç, G. G., Ersoy, N., Basak, O., Kaplan, K., Sevinç, K., et al. (2019). Robust, long-term culture of endoderm-derived demonstrated that malaria infection started from the hepatoblst stage to hepatocytes ( $\mathrm{Ng}$ et al., 2015). However, due to the immaturity of human PSC-derived hepatocytes, they have limited potential to test anti-malaria prodrugs that require activation by hepatocyte-specific metabolizing enzymes. Using small chemicals to improve maturation, the authors showed cell response to antimalaria prodrug primaquine, which indicates the importance of maturity for drug tesing.

In conclusion, human PSC-LOs have not yet been widely used in modeling infectious diseases partly due to their immaturity and shortage of recognition. With the improvement of maturation, PSC-LOs are expected to show more values in the study of infectious diseases and the development of therapies.

\section{CONCLUSION}

There is no doubt about the potential values of human PSCLOs in regenerative medicine, disease modeling, and drug development. However, it has been very slow for human PSCLOs moving to applications. For regenerative medicine, human PSC-LOs must be safe and effective in vivo, which requires the use of xeno-free materials in the generation and expansion of human PSC-LOs, reliable genome editing technique, and effective in vivo delivery methods (Figure 1). Meanwhile, genetic and epigenetic stability must be monitored thoroughout the generation and culture of PSC-LOs. For disease modeling and drug development, improving maturity, reducing heterogeneity, and increasing complexity are current challenges to be solved (Figure 1). By working with biomaterial scientists, bioengineers, pharmacists, and physicists, researchers can nowadays design novel 3D cell culture platforms to make human PSC-LOs suitable for intended applications. All of these will contribute to treating patients with liver diseases.

\section{AUTHOR CONTRIBUTIONS}

Y-RL: conceptualization, supervision, project administration, and funding acquisition. Y-RL, MC, and MB: writing-original draft preparation. Y-RL and MC: writing-review and editing. All authors have read and agreed to the published version of the manuscript.

\section{ACKNOWLEDGMENTS}

We would like to thank the research funding from Fudan University.

hepatic organoids for disease modeling. Stem Cell Rep. 13, 627-641. doi: 10.1016/j.stemcr.2019.08.007

Amps, K., Andrews, P. W., Anyfantis, G., Armstrong, L., Avery, S., Baharvand, H., et al. (2011). Screening ethnically diverse human embryonic stem cells identifies a chromosome 20 minimal amplicon conferring growth advantage. Nat. Biotechnol. 29, 1132-1144. doi: $10.1038 /$ nbt.2051 
Arez, F., Rodrigues, A. F., Brito, C., and Alves, P. M. (2021). Bioengineered liver cell models of hepatotropic infections. Viruses 13:773.

Asai, A., Aihara, E., Watson, C., Mourya, R., Mizuochi, T., Shivakumar, P., et al. (2017). Paracrine signals regulate human liver organoid maturation from induced pluripotent stem cells. Development 144, 1056-1064. doi: 10.1242/dev. 142794

Ashmore-Harris, C., Blackford, S. J., Grimsdell, B., Kurtys, E., Glatz, M. C., Rashid, T. S., et al. (2019). Reporter gene-engineering of human induced pluripotent stem cells during differentiation renders in vivo traceable hepatocyte-like cells accessible. Stem Cell Res. 41:101599. doi: 10.1016/j.scr.2019.101599

Assou, S., Girault, N., Plinet, M., Bouckenheimer, J., Sansac, C., Combe, M., et al. (2020). Recurrent genetic abnormalities in human pluripotent stem cells: definition and routine detection in culture supernatant by targeted droplet digital PCR. Stem Cell Rep. 14, 1-8. doi: 10.1016/j.stemcr.2019.12.004

Baptista, P. M., Siddiqui, M. M., Lozier, G., Rodriguez, S. R., Atala, A., and Soker, S. (2011). The use of whole organ decellularization for the generation of a vascularized liver organoid. Hepatology 53, 604-617.

Baxter, M., Withey, S., Harrison, S., Segeritz, C.-P., Zhang, F., Atkinson-Dell, R., et al. (2015). Phenotypic and functional analyses show stem cell-derived hepatocyte-like cells better mimic fetal rather than adult hepatocytes. J. Hepatol. 62, 581-589. doi: 10.1016/j.jhep.2014.10.016

Bhutani, K., Nazor, K. L., Williams, R., Tran, H., Dai, H., Džakula, Ž, et al. (2016). Whole-genome mutational burden analysis of three pluripotency induction methods. Nat. Commun. 7:10536. doi: 10.1038/ncomms10536

Boulting, G. L., Kiskinis, E., Croft, G. F., Amoroso, M. W., Oakley, D. H., Wainger, B. J., et al. (2011). A functionally characterized test set of human induced pluripotent stem cells. Nat. Biotechnol. 29, 279-286.

Brooks, A., Liang, X., Zhang, Y., Zhao, C. X., Roberts, M. S., Wang, H., et al. (2021). Liver organoid as a 3D in vitro model for drug validation and toxicity assessment. Pharmacol. Res. 169, 105608. doi: 10.1016/j.phrs.2021.105608

Broutier, L., Mastrogiovanni, G., Verstegen, M. M. A., Francies, H. E., Gavarró, L. M., Bradshaw, C. R., et al. (2017). Human primary liver cancer-derived organoid cultures for disease modeling and drug screening. Nat. Med. 23, 1424-1435. doi: 10.1038/nm.4438

Bulutoglu, B., Rey-Bedón, C., Kang, Y. B. A., Mert, S., Yarmush, M. L., and Usta, O. B. (2019). A microfluidic patterned model of non-alcoholic fatty liver disease: applications to disease progression and zonation. Lab Chip 19, 3022-3031. doi: $10.1039 / \mathrm{c} 91 \mathrm{c} 00354 \mathrm{a}$

Burdick, J. A., and Prestwich, G. D. (2011). Hyaluronic acid hydrogels for biomedical applications. Adv. Mater. 23, H41-H56.

Burrows, C. K., Banovich, N. E., Pavlovic, B. J., Patterson, K., Gallego Romero, I., Pritchard, J. K., et al. (2016). Genetic variation, not cell type of origin, underlies the majority of identifiable regulatory differences in iPSCs. PLoS Genet. 12:e1005793. doi: 10.1371/journal.pgen.1005793

Cahan, P., and Daley, G. Q. (2013). Origins and implications of pluripotent stem cell variability and heterogeneity. Nat. Rev. Mol. Cell Biol. 14, 357-368.

Collins, S. D., Yuen, G., Tu, T., Budzinska, M. A., Spring, K., Bryant, K., et al. (2019). "In vitro models of the liver: disease modeling, drug discovery and clinical applications," in Hepatocellular Carcinoma, ed. J. E. E. Tirnitz-Parker (Brisbane, QLD: Codon Publications).

D’Antonio, M., Benaglio, P., Jakubosky, D., Greenwald, W. W., Matsui, H., Donovan, M. K., et al. (2018). Insights into the mutational burden of human induced pluripotent stem cells from an integrative multi-omics approach. Cell Rep. 24, 883-894. doi: 10.1016/j.celrep.2018.06.091

Davidson, M. D., and Khetani, S. R. (2020). Intermittent starvation extends the functional lifetime of primary human hepatocyte cultures. Toxicol. Sci. 174, 266-277. doi: 10.1093/toxsci/kfaa003

Deegan, D. B., Zimmerman, C., Skardal, A., Atala, A., and Shupe, T. D. (2016). Stiffness of hyaluronic acid gels containing liver extracellular matrix supports human hepatocyte function and alters cell morphology. J. Mech. Behav. Biomed. Mater. 55, 87-103. doi: 10.1016/j.jmbbm.2015.10.016

Du, C., Narayanan, K., Leong, M. F., and Wan, A. C. (2014). Induced pluripotent stem cell-derived hepatocytes and endothelial cells in multi-component hydrogel fibers for liver tissue engineering. Biomaterials 35, 6006-6014. doi: 10.1016/j.biomaterials.2014.04.011

Faulkner-Jones, A., Fyfe, C., Cornelissen, D.-J., Gardner, J., King, J., Courtney, A., et al. (2015). Bioprinting of human pluripotent stem cells and their directed differentiation into hepatocyte-like cells for the generation of mini-livers in 3D. Biofabrication 7:044102. doi: 10.1088/1758-5090/7/4/044102

Fedorovich, N. E., Alblas, J., de Wijn, J. R., Hennink, W. E., Verbout, A. J., and Dhert, W. J. (2007). Hydrogels as extracellular matrices for skeletal tissue engineering: state-of-the-art and novel application in organ printing. Tissue Eng. 13, 1905-1925. doi: 10.1089/ten.2006.0175

Fu, Y., Foden, J. A., Khayter, C., Maeder, M. L., Reyon, D., Joung, J. K., et al. (2013). High-frequency off-target mutagenesis induced by CRISPR-Cas nucleases in human cells. Nat. Biotechnol. 31, 822-826.

Galle, P. R., Hagelstein, J., Kommerell, B., Volkmann, M., Schranz, P., and Zentgraf, H. (1994). In vitro experimental infection of primary human hepatocytes with hepatitis B virus. Gastroenterology 106, 664-673.

Ganesh, K., Wu, C., O’Rourke, K. P., Szeglin, B. C., Zheng, Y., Sauvé, C. G., et al. (2019). A rectal cancer organoid platform to study individual responses to chemoradiation. Nat. Med. 25, 1607-1614. doi: 10.1038/s41591-019-0584-2

Gieseck, R. L. III, Hannan, N. R., Bort, R., Hanley, N. A., Drake, R. A., Cameron, G. W., et al. (2014). Maturation of induced pluripotent stem cell derived hepatocytes by 3D-culture. PLoS One 9:e86372. doi: 10.1371/journal.pone. 0086372

Giobbe, G. G., Crowley, C., Luni, C., Campinoti, S., Khedr, M., Kretzschmar, K., et al. (2019). Extracellular matrix hydrogel derived from decellularized tissues enables endodermal organoid culture. Nat. Commun. 10, 1-14. doi: 10.1038/ s41467-019-13605-4

Goulart, E., de Caires-Junior, L. C., Telles-Silva, K. A., Araujo, B. H. S., Kobayashi, G. S., Musso, C. M., et al. (2019). Adult and iPS-derived non-parenchymal cells regulate liver organoid development through differential modulation of Wnt and TGF- $\beta$. Stem Cell. Res. Ther. 10, 1-11. doi: 10.1186/s13287-019-1367-x

Grskovic, M., Javaherian, A., Strulovici, B., and Daley, G. Q. (2011). Induced pluripotent stem cells-opportunities for disease modelling and drug discovery. Nat. Rev. Drug Discov. 10, 915-929. doi: 10.1038/nrd3577

Guan, Y., Xu, D., Garfin, P. M., Ehmer, U., Hurwitz, M., Enns, G., et al. (2017). Human hepatic organoids for the analysis of human genetic diseases. JCI Insight 2:e94954.

Gupta, S., Rajvanshi, P., Sokhi, R., Slehria, S., Yam, A., Kerr, A., et al. (1999). Entry and integration of transplanted hepatocytes in rat liver plates occur by disruption of hepatic sinusoidal endothelium. Hepatology 29, 509-519. doi: 10.1002/hep.510290213

Gural, N., Mancio-Silva, L., He, J., and Bhatia, S. N. (2018). Engineered livers for infectious diseases. Cell. Mol. Gastroenterol. Hepatol. 5, 131-144.

Hall, Z., Bond, N. J., Ashmore, T., Sanders, F., Ament, Z., Wang, X., et al. (2017). Lipid zonation and phospholipid remodeling in nonalcoholic fatty liver disease. Hepatology 65, 1165-1180. doi: 10.1002/hep.28953

Hendriks, D., Artegiani, B., Hu, H., de Sousa Lopes, S. C., and Clevers, H. (2021). Establishment of human fetal hepatocyte organoids and CRISPR-Cas9-based gene knockin and knockout in organoid cultures from human liver. Nat. Protoc. 16, 182-217. doi: 10.1038/s41596-020-00411-2

Hong, C.-H., Sohn, H.-J., Lee, H.-J., Cho, H.-I., and Kim, T.-G. (2017). Antigen presentation by individually transferred HLA class i genes in HLA-A, HLAB, HLA-C null human cell line generated using the multiplex CRISPR-Cas9 system. J. Immunother. 40, 201-210. doi: 10.1097/CJI.0000000000000176

Hou, Z., Zhang, Y., Propson, N. E., Howden, S. E., Chu, L.-F., Sontheimer, E. J., et al. (2013). Efficient genome engineering in human pluripotent stem cells using Cas9 from Neisseria meningitidis. Proc. Natl. Acad. Sci. U.S.A. 110, 15644-15649. doi: 10.1073/pnas. 1313587110

Hsia, G. S. P., Esposito, J., da Rocha, L. A., Ramos, S. L. G., and Okamoto, O. K. (2021). Clinical application of human induced pluripotent stem cell-derived organoids as an alternative to organ transplantation. Stem Cells Int. 2021, 6632160. doi: 10.1155/2021/6632160

Hu, H., Gehart, H., Artegiani, B., LÖpez-Iglesias, C., Dekkers, F., Basak, O., et al. (2018). Long-term expansion of functional mouse and human hepatocytes as 3D organoids. Cell 175, 1591-1606.e1519.

Huang, S. (2009). Non-genetic heterogeneity of cells in development: more than just noise. Development 136, 3853-3862.

Huch, M., Gehart, H., Van Boxtel, R., Hamer, K., Blokzijl, F., Verstegen, M. M., et al. (2015). Long-term culture of genome-stable bipotent stem cells from adult human liver. Cell 160, 299-312. doi: 10.1016/j.cell.2014.11.050

Inoue, H., and Yamanaka, S. (2011). The use of induced pluripotent stem cells in drug development. Clin. Pharmacol. Ther. 89, 655-661. 
Janani, G., and Mandal, B. B. (2021). Mimicking physiologically relevant hepatocyte zonation using immunomodulatory silk liver extracellular matrix scaffolds toward a bioartificial liver platform. ACS Appl. Mater. Interfaces 13, 24401-24421. doi: 10.1021/acsami.1c00719

Ji, J., Ng, S. H., Sharma, V., Neculai, D., Hussein, S., Sam, M., et al. (2012). Elevated coding mutation rate during the reprogramming of human somatic cells into induced pluripotent stem cells. Stem Cells 30, 435-440. doi: 10.1002/stem.1011

Jung, K. B., Lee, H., Son, Y. S., Lee, M.-O., Kim, Y.-D., Oh, S. J., et al. (2018). Interleukin-2 induces the in vitro maturation of human pluripotent stem cellderived intestinal organoids. Nat. Commun. 9:3039. doi: 10.1038/s41467-01805450-8

Kietzmann, T. (2017). Metabolic zonation of the liver: the oxygen gradient revisited. Redox Biol. 11, 622-630. doi: 10.1016/j.redox.2017.01.012

Kilpinen, H., Goncalves, A., Leha, A., Afzal, V., Alasoo, K., Ashford, S., et al. (2017). Common genetic variation drives molecular heterogeneity in human iPSCs. Nature 546, 370-375.

Kim, K., Zhao, R., Doi, A., Ng, K., Unternaehrer, J., Cahan, P., et al. (2011). Donor cell type can influence the epigenome and differentiation potential of human induced pluripotent stem cells. Nat. Biotechnol. 29, 1117-1119.

Kleinstiver, B. P., Pattanayak, V., Prew, M. S., Tsai, S. Q., Nguyen, N. T., Zheng, Z., et al. (2016). High-fidelity CRISPR-Cas9 nucleases with no detectable genome-wide off-target effects. Nature 529, 490-495. doi: 10.1038/nature16526

Klotz, B. J., Oosterhoff, L. A., Utomo, L., Lim, K. S., Vallmajo-Martin, Q., Clevers, H., et al. (2019). A versatile biosynthetic hydrogel platform for engineering of tissue analogues. Adv. Healthcare Mater. 8:e1900979. doi: 10.1002/adhm. 201900979

Koepsell, H., Lips, K., and Volk, C. (2007). Polyspecific organic cation transporters: structure, function, physiological roles, and biopharmaceutical implications. Pharm. Res. 24, 1227-1251. doi: 10.1007/s11095-007-9254-z

Krüger, M., Oosterhoff, L. A., van Wolferen, M. E., Schiele, S. A., Walther, A., Geijsen, N., et al. (2020). Cellulose nanofibril hydrogel promotes hepatic differentiation of human liver organoids. Adv. Healthcare Mater. 9:e1901658. doi: 10.1002/adhm.201901658

Kryou, C., Leva, V., Chatzipetrou, M., and Zergioti, I. (2019). Bioprinting for liver transplantation. Bioengineering 6:95. doi: 10.3390/bioengineering6040095

Kuijk, E., Jager, M., van der Roest, B., Locati, M. D., Van Hoeck, A., Korzelius, J., et al. (2020). The mutational impact of culturing human pluripotent and adult stem cells. Nat. Commun. 11:2493.

Kuo, C. J., and Curtis, C. (2018). Organoids Reveal Cancer Dynamics. Berlin: Nature Publishing Group.

Lancaster, M. A., Renner, M., Martin, C.-A., Wenzel, D., Bicknell, L. S., Hurles, M. E., et al. (2013). Cerebral organoids model human brain development and microcephaly. Nature 501, 373-379.

Laurent, L. C., Ulitsky, I., Slavin, I., Tran, H., Schork, A., Morey, R., et al. (2011). Dynamic changes in the copy number of pluripotency and cell proliferation genes in human ESCs and iPSCs during reprogramming and time in culture. Cell Stem Cell 8, 106-118. doi: 10.1016/j.stem.2010.12.003

Lee, G., Kim, H., Park, J. Y., Kim, G., Han, J., Chung, S., et al. (2021). Generation of uniform liver spheroids from human pluripotent stem cells for imaging-based drug toxicity analysis. Biomaterials 269, 120529. doi: 10.1016/j.biomaterials. 2020.120529

Lee, J., Sheen, J. H., Lim, O., Lee, Y., Ryu, J., Shin, D., et al. (2020). Abrogation of HLA surface expression using CRISPR/Cas9 genome editing: a step toward universal $\mathrm{T}$ cell therapy. Sci. Rep. 10, 1-10. doi: 10.1038/s41598-020-74772-9

Leung, A. W., Broton, C., Bogacheva, M. S., Xiao, A. Z., Garcia-Castro, M. I., and Lou, Y.-R. (2020). RNA-based CRISPR-mediated loss-of-function mutagenesis in human pluripotent stem cells. J. Mol. Biol. 432, 3956-3964. doi: 10.1016/j. jmb.2020.04.017

Liang, G., and Zhang, Y. (2013). Genetic and epigenetic variations in iPSCs: potential causes and implications for application. Cell Stem Cell 13, 149-159.

Lin, X., Tang, J., and Lou, Y.-R. (2021). Human pluripotent stem-cell-derived models as a missing link in drug discovery and development. Pharmaceuticals 14:525. doi: 10.3390/ph14060525

Lou, Y.-R., and Leung, A. W. (2018). Next generation organoids for biomedical research and applications. Biotechnol. Adv. 36, 132-149.
Lou, Y.-R., Kanninen, L., Kuisma, T., Niklander, J., Noon, L. A., Burks, D., et al. (2014). The use of nanofibrillar cellulose hydrogel as a flexible threedimensional model to culture human pluripotent stem cells. Stem Cells Dev. 23, 380-392. doi: 10.1089/scd.2013.0314

Lucendo-Villarin, B., Meseguer-Ripolles, J., Drew, J., Fischer, L., Ma, E., Flint, O., et al. (2020). Development of a cost-effective automated platform to produce human liver spheroids for basic and applied research. Biofabrication 13:015009. doi: 10.1088/1758-5090/abbdb2

Lynch, S., Pridgeon, C. S., Duckworth, C. A., Sharma, P., Park, B. K., and Goldring, C. E. P. (2019). Stem cell models as an in vitro model for predictive toxicology. Biochem. J. 476, 1149-1158. doi: 10.1042/BCJ20170780

Mandai, M., Watanabe, A., Kurimoto, Y., Hirami, Y., Morinaga, C., Daimon, T., et al. (2017). Autologous induced stem-cell-derived retinal cells for macular degeneration. N. Engl. J. Med. 376, 1038-1046.

Manou, D., Caon, I., Bouris, P., Triantaphyllidou, I.-E., Giaroni, C., Passi, A., et al. (2019). The complex interplay between extracellular matrix and cells in tissues. Extracell. Matrix 1952, 1-20.

Mansour, A. A., Gonçalves, J. T., Bloyd, C. W., Li, H., Fernandes, S., Quang, D., et al. (2018). An in vivo model of functional and vascularized human brain organoids. Nat. Biotechnol. 36, 432-441.

Martins-Taylor, K., Nisler, B. S., Taapken, S. M., Compton, T., Crandall, L., Montgomery, K. D., et al. (2011). Recurrent copy number variations in human induced pluripotent stem cells. Nat. Biotechnol. 29, 488-491.

Mayshar, Y., Ben-David, U., Lavon, N., Biancotti, J.-C., Yakir, B., Clark, A. T., et al. (2010). Identification and classification of chromosomal aberrations in human induced pluripotent stem cells. Cell Stem Cell 7, 521-531. doi: 10.1016/j.stem. 2010.07.017

Mekhoubad, S., Bock, C., De Boer, A. S., Kiskinis, E., Meissner, A., and Eggan, K. (2012). Erosion of dosage compensation impacts human iPSC disease modeling. Cell Stem Cell 10, 595-609.

Miller, A. J., Dye, B. R., Ferrer-Torres, D., Hill, D. R., Overeem, A. W., Shea, L. D., et al. (2019). Generation of lung organoids from human pluripotent stem cells in vitro. Nat. Protoc. 14, 518-540.

Minami, T., Ishii, T., Yasuchika, K., Fukumitsu, K., Ogiso, S., Miyauchi, Y., et al. (2019). Novel hybrid three-dimensional artificial liver using human induced pluripotent stem cells and a rat decellularized liver scaffold. Regen. Ther. 10, 127-133. doi: 10.1016/j.reth.2019.03.002

Mun, S. J., Hong, Y.-H., Ahn, H.-S., Ryu, J.-S., Chung, K.-S., and Son, M. J. (2020). Long-term expansion of functional human pluripotent stem cellderived hepatic organoids. Int. J. Stem Cells 13:279.

Mun, S. J., Lee, J., Chung, K. S., Son, M. Y., and Son, M. J. (2021). Effect of microbial short-chain fatty acids on CYP3A4-mediated metabolic activation of human pluripotent stem cell-derived liver organoids. Cells 10:126. doi: 10.3390/ cells 10010126

Muthuswamy, S. K. (2018). Organoid models of cancer explode with possibilities. Cell Stem Cell 22, 290-291. doi: 10.1016/j.stem.2018.02.010

Nagamoto, Y., Takayama, K., Ohashi, K., Okamoto, R., Sakurai, F., Tachibana, M., et al. (2016). Transplantation of a human iPSC-derived hepatocyte sheet increases survival in mice with acute liver failure. J. Hepatol. 64, 1068-1075. doi: 10.1016/j.jhep.2016.01.004

National Center For Health Statistics (2021). Health, United States, 2019. Hyattsville, MD: National Center For Health Statistics.

Ng, S. S., Saeb-Parsy, K., Blackford, S. J. I., Segal, J. M., Serra, M. P., HorcasLopez, M., et al. (2018). Human iPS derived progenitors bioengineered into liver organoids using an inverted colloidal crystal poly (ethylene glycol) scaffold. Biomaterials 182, 299-311. doi: 10.1016/j.biomaterials.2018.07.043

Ng, S., Schwartz, R. E., March, S., Galstian, A., Gural, N., Shan, J., et al. (2015). Human iPSC-derived hepatocyte-like cells support Plasmodium liver-stage infection in vitro. Stem Cell Rep. 4, 348-359. doi: 10.1016/j.stemcr.2015.01.002

Nie, Y.-Z., Zheng, Y.-W., Miyakawa, K., Murata, S., Zhang, R.-R., Sekine, K., et al. (2018). Recapitulation of hepatitis B virus-host interactions in liver organoids from human induced pluripotent stem cells. EBioMedicine 35, 114-123.

Nishizawa, M., Chonabayashi, K., Nomura, M., Tanaka, A., Nakamura, M., Inagaki, A., et al. (2016). Epigenetic variation between human induced pluripotent stem cell lines is an indicator of differentiation capacity. Cell Stem Cell 19, 341-354. doi: 10.1016/j.stem.2016.06.019 
Nuñez, J. K., Harrington, L. B., and Doudna, J. A. (2016). Chemical and biophysical modulation of Cas9 for tunable genome engineering. ACS Chem. Biol. 11, 681-688. doi: 10.1021/acschembio.5b01019

Oberwallner, B., Brodarac, A., Choi, Y. H., Saric, T., Anić, P., Morawietz, L., et al. (2014). Preparation of cardiac extracellular matrix scaffolds by decellularization of human myocardium. J. Biomed. Mater. Res. Part A 102, 3263-3272.

Ogawa, S., Surapisitchat, J., Virtanen, C., Niapour, M., Sugamori, K. S., Wang, S., et al. (2013). Three-dimensional culture and cAMP signaling promote the maturation of human pluripotent stem cell-derived hepatocytes. Development 140, 3285-3296. doi: 10.1242/dev.090266

Ogoke, O., Maloy, M., and Parashurama, N. (2021). The science and engineering of stem cell-derived organoids-examples from hepatic, biliary, and pancreatic tissues. Biol. Rev. Camb. Philos. Soc. 96, 179-204. doi: 10.1111/brv.12650

Okita, K., Matsumura, Y., Sato, Y., Okada, A., Morizane, A., Okamoto, S., et al. (2011). A more efficient method to generate integration-free human iPS cells. Nat. Methods 8, 409-412.

Orkin, R., Gehron, P., Mcgoodwin, E. B., Martin, G., Valentine, T., and Swarm, R. (1977). A murine tumor producing a matrix of basement membrane. J. Exp. Med. 145, 204-220.

Ott, H. C., Matthiesen, T. S., Goh, S.-K., Black, L. D., Kren, S. M., Netoff, T. I., et al. (2008). Perfusion-decellularized matrix: using nature's platform to engineer a bioartificial heart. Nat. Med. 14, 213-221. doi: 10.1038/nm1684

Ouchi, R., Togo, S., Kimura, M., Shinozawa, T., Koido, M., Koike, H., et al. (2019). Modeling steatohepatitis in humans with pluripotent stem cell-derived organoids. Cell Metab. 30, 374-384.e376.

Papapetrou, E. P. (2016). Patient-derived induced pluripotent stem cells in cancer research and precision oncology. Nat. Med. 22, 1392-1401.

Pauli, C., Hopkins, B. D., Prandi, D., Shaw, R., Fedrizzi, T., Sboner, A., et al. (2017). Personalized in vitro and in vivo cancer models to guide precision medicine. Cancer Discov. 7, 462-477.

Peng, W. C., Logan, C. Y., Fish, M., Anbarchian, T., Aguisanda, F., ÁlvarezVarela, A., et al. (2018). Inflammatory cytokine TNF $\alpha$ promotes the long-term expansion of primary hepatocytes in 3D culture. Cell 175, 1607-1619. e1615 doi: 10.1016/j.cell.2018.11.012

Pettinato, G., Lehoux, S., Ramanathan, R., Salem, M. M., He, L.-X., Muse, O., et al. (2019). Generation of fully functional hepatocyte-like organoids from human induced pluripotent stem cells mixed with endothelial cells. Sci. Rep. 9, 1-21. doi: 10.1038/s41598-019-45514-3

Planas-Paz, L., Orsini, V., Boulter, L., Calabrese, D., Pikiolek, M., Nigsch, F., et al. (2016). The RSPO-LGR4/5-ZNRF3/RNF43 module controls liver zonation and size. Nat. Cell Biol. 18, 467-479.

Plummer, S., Wallace, S., Ball, G., Lloyd, R., Schiapparelli, P., Quiñones-Hinojosa, A., et al. (2019). A human iPSC-derived 3D platform using primary brain cancer cells to study drug development and personalized medicine. Sci. Rep. 9, 1-11. doi: 10.1038/s41598-018-38130-0

Polo, J. M., Liu, S., Figueroa, M. E., Kulalert, W., Eminli, S., Tan, K. Y., et al. (2010). Cell type of origin influences the molecular and functional properties of mouse induced pluripotent stem cells. Nat. Biotechnol. 28, 848-855. doi: 10.1038/nbt.1667

Pope, I., Masia, F., Ewan, K., Jimenez-Pascual, A., Dale, T. C., Siebzehnrubl, F. A., et al. (2021). Identifying subpopulations in multicellular systems by quantitative chemical imaging using label-free hyperspectral CARS microscopy. Analyst 146, 2277-2291. doi: 10.1039/d0an02381g

Popper, H., and Schaffner, F. (1957). Liver: Structure And Function. New York, NY: McGraw Hill.

Prodanov, L., Jindal, R., Bale, S. S., Hegde, M., McCarty, W. J., Golberg, I., et al. (2016). Long-term maintenance of a microfluidic 3D human liver sinusoid. Biotechnol. Bioeng. 113, 241-246. doi: 10.1002/bit.25700

Raju, R., Chau, D., Cho, D. S., Park, Y., Verfaillie, C. M., and Hu, W.-S. (2017). Cell expansion during directed differentiation of stem cells toward the hepatic lineage. Stem Cells Dev. 26, 274-284.

Ramli, M. N. B., Lim, Y. S., Koe, C. T., Demircioglu, D., Tng, W., Gonzales, K. A. U., et al. (2020). Human pluripotent stem cell-derived organoids as models of liver disease. Gastroenterology 159, 1471-1486 e1412. doi: 10.1053/j.gastro.2020.06.010

Ran, F. A., Cong, L., Yan, W. X., Scott, D. A., Gootenberg, J. S., Kriz, A. J., et al. (2015). In vivo genome editing using Staphylococcus aureus Case. Nature 520, 186-191.
Rashidi, H., Luu, N. T., Alwahsh, S. M., Ginai, M., Alhaque, S., Dong, H., et al. (2018). 3D human liver tissue from pluripotent stem cells displays stable phenotype in vitro and supports compromised liver function in vivo. Arch. Toxicol. 92, 3117-3129. doi: 10.1007/s00204-018-2280-2

Reintjes, J., Duncan, M. D., and Manuccia, T. J. (1982). "Picosecond coherent antistokes raman scattering (CARS) Microscope," in Proceedings of the SPIE 0322, Picosecond Lasers and Applications, Los Angeles, CA.

Roelandt, P., Obeid, S., Paeshuyse, J., Vanhove, J., Van Lommel, A., Nahmias, Y., et al. (2012). Human pluripotent stem cell-derived hepatocytes support complete replication of hepatitis C virus. J. Hepatol. 57, 246-251. doi: 10.1016/ j.jhep.2012.03.030

Rossi, G., Broguiere, N., Miyamoto, M., Boni, A., Guiet, R., Girgin, M., et al. (2021). Capturing cardiogenesis in gastruloids. Cell Stem Cell 28, 230-240. e236. doi: $10.1016 /$ j.stem.2020.10.013

Schene, I. F., Joore, I. P., Oka, R., Mokry, M., van Vugt, A. H. M., van Boxtel, R., et al. (2020). Prime editing for functional repair in patient-derived disease models. Nat. Commun. 11:5352. doi: 10.1038/s41467-020-19136-7

Schneeberger, K., Sánchez-Romero, N., Ye, S., van Steenbeek, F. G., Oosterhoff, L. A., Pla Palacin, I., et al. (2020). Large-scale production of LGR5-positive bipotential human liver stem cells. Hepatology 72, 257-270. doi: 10.1002/hep. 31037

Schulze, A., Mills, K., Weiss, T. S., and Urban, S. (2012). Hepatocyte polarization is essential for the productive entry of the hepatitis B virus. Hepatology 55 , 373-383. doi: 10.1002/hep.24707

Schwartz, R. E., Trehan, K., Andrus, L., Sheahan, T. P., Ploss, A., Duncan, S. A., et al. (2012). Modeling hepatitis $C$ virus infection using human induced pluripotent stem cells. Proc. Natl. Acad. Sci. U.S.A. 109, 2544-2548.

Schwarz, S., Koerber, L., Elsaesser, A. F., Goldberg-Bockhorn, E., Seitz, A. M., Dürselen, L., et al. (2012). Decellularized cartilage matrix as a novel biomatrix for cartilage tissue-engineering applications. Tissue Eng. Part A 18, 2195-2209. doi: 10.1089/ten.TEA.2011.0705

Serra, D., Mayr, U., Boni, A., Lukonin, I., Rempfler, M., Meylan, L. C., et al. (2019). Self-organization and symmetry breaking in intestinal organoid development. Nature 569, 66-72. doi: 10.1038/s41586-019-1146-y

Sgodda, M., Dai, Z., Zweigerdt, R., Sharma, A. D., Ott, M., and Cantz, T. (2017). A scalable approach for the generation of human pluripotent stem cell-derived hepatic organoids with sensitive hepatotoxicity features. Stem Cells Dev. 26, 1490-1504. doi: 10.1089/scd.2017.0023

Sharma, S., Raju, R., Sui, S., and Hu, W. S. (2011). Stem cell culture engineeringprocess scale up and beyond. Biotechnol. J. 6, 1317-1329. doi: 10.1002/biot. 201000435

Shlomai, A., Schwartz, R. E., Ramanan, V., Bhatta, A., de Jong, Y. P., Bhatia, S. N., et al. (2014). Modeling host interactions with hepatitis B virus using primary and induced pluripotent stem cell-derived hepatocellular systems. Proc. Natl. Acad. Sci. U.S.A. 111, 12193-12198. doi: 10.1073/pnas.1412631111

Si-Tayeb, K., Lemaigre, F. P., and Duncan, S. A. (2010). Organogenesis and development of the liver. Dev. Cell 18, 175-189.

Song, W., Lu, Y.-C., Frankel, A. S., An, D., Schwartz, R. E., and Ma, M. (2015). Engraftment of human induced pluripotent stem cell-derived hepatocytes in immunocompetent mice via 3D co-aggregation and encapsulation. Sci. Rep. 5, 1-13. doi: $10.1038 /$ srep16884

Sorrentino, G., Rezakhani, S., Yildiz, E., Nuciforo, S., Heim, M. H., Lutolf, M. P., et al. (2020). Mechano-modulatory synthetic niches for liver organoid derivation. Nat. Commun. 11, 1-10. doi: 10.1038/s41467-020-17161-0

Stieger, B. (2011). The role of the sodium-taurocholate cotransporting polypeptide (NTCP) and of the bile salt export pump (BSEP) in physiology and pathophysiology of bile formation. Drug Transporters 201, 205-259.

Sugimoto, S., and Sato, T. (2017). "Establishment of 3D intestinal organoid cultures from intestinal stem cells," in 3D Cell Culture. Methods in Molecular Biology, ed. Z. Koledova (Berlin: Springer), 97-105.

Szot, G. L., Yadav, M., Lang, J., Kroon, E., Kerr, J., Kadoya, K., et al. (2015). Tolerance induction and reversal of diabetes in mice transplanted with human embryonic stem cell-derived pancreatic endoderm. Cell Stem Cell 16, 148-157. doi: 10.1016/j.stem.2014.12.001

Takahashi, K., Tanabe, K., Ohnuki, M., Narita, M., Ichisaka, T., Tomoda, K., et al. (2007). Induction of pluripotent stem cells from adult human fibroblasts by defined factors. Cell 131, 861-872. 
Takasato, M., Pei, X. E., Chiu, H. S., Maier, B., Baillie, G. J., Ferguson, C., et al. (2015). Kidney organoids from human iPS cells contain multiple lineages and model human nephrogenesis. Nature 526, 564-568.

Takebe, T., Sekine, K., Enomura, M., Koike, H., Kimura, M., Ogaeri, T., et al. (2013). Vascularized and functional human liver from an iPSC-derived organ bud transplant. Nature 499, 481-484. doi: 10.1038/nature12271

Takebe, T., Sekine, K., Kimura, M., Yoshizawa, E., Ayano, S., Koido, M., et al. (2017). Massive and reproducible production of liver buds entirely from human pluripotent stem cells. Cell Rep. 21, 2661-2670. doi: 10.1016/j.celrep.2017.11. 005

Tam, P. P. L., and Loebel, D. A. F. (2007). Gene function in mouse embryogenesis: get set for gastrulation. Nat. Rev. Genet. 8, 368-381. doi: 10.1038/nrg2084

Taylor, C. J., Peacock, S., Chaudhry, A. N., Bradley, J. A., and Bolton, E. M. (2012). Generating an iPSC bank for HLA-matched tissue transplantation based on known donor and recipient HLA types. Cell Stem Cell 11, 147-152. doi: 10.1016/j.stem.2012.07.014

Thompson, W. L., and Takebe, T. (2021). Human liver model systems in a dish. Dev. Growth Differ. 63, 47-58. doi: 10.1111/dgd.12708

Touboul, T., Hannan, N. R. F., Corbineau, S., Martinez, A., Martinet, C., Branchereau, S., et al. (2010). Generation of functional hepatocytes from human embryonic stem cells under chemically defined conditions that recapitulate liver development. Hepatology 51, 1754-1765. doi: 10.1002/hep.23506

Tsuchida, T., Murata, S., Hasegawa, S., Mikami, S., Enosawa, S., Hsu, H.-C., et al. (2020). Investigation of clinical safety of human iPS cell-derived liver organoid transplantation to infantile patients in porcine model. Cell Transplant 29:0963689720964384. doi: 10.1177/0963689720964384

Tsuchida, T., Murata, S., Matsuki, K., Mori, A., Matsuo, M., Mikami, S., et al. (2019). The Regenerative effect of portal vein injection of liver organoids by retrorsine/partial hepatectomy in rats. Int. J. Mol. Sci. 21:178. doi: 10.3390/ ijms 21010178

Tsuji, O., Miura, K., Okada, Y., Fujiyoshi, K., Mukaino, M., Nagoshi, N., et al. (2010). Therapeutic potential of appropriately evaluated safe-induced pluripotent stem cells for spinal cord injury. Proc. Natl. Acad. Sci. U.S.A. 107, 12704-12709. doi: 10.1073/pnas.0910106107

Uygun, B. E., Soto-Gutierrez, A., Yagi, H., Izamis, M.-L., Guzzardi, M. A., Shulman, C., et al. (2010). Organ reengineering through development of a transplantable recellularized liver graft using decellularized liver matrix. Nat. Med. 16:814.

Valamehr, B., Robinson, M., Abujarour, R., Rezner, B., Vranceanu, F., Le, T., et al. (2014). Platform for induction and maintenance of transgene-free hiPSCs resembling ground state pluripotent stem cells. Stem Cell Rep. 2, 366-381. doi: 10.1016/j.stemcr.2014.01.014

van Ineveld, R. L., Ariese, H. C. R., Wehrens, E. J., Dekkers, J. F., and Rios, A. C. (2020). Single-cell resolution three-dimensional imaging of intact organoids. J. Vis. Exp. doi: 10.3791/60709

Vassena, R., Montserrat, N., Carrasco Canal, B., Aran, B., de Oñate, L., Veiga, A., et al. (2012). Accumulation of instability in serial differentiation and reprogramming of parthenogenetic human cells. Hum. Mol. Genet. 21, 33663373. doi: $10.1093 / \mathrm{hmg} / \mathrm{dds} 168$

Vlachogiannis, G., Hedayat, S., Vatsiou, A., Jamin, Y., Fernández-Mateos, J., Khan, K., et al. (2018). Patient-derived organoids model treatment response of metastatic gastrointestinal cancers. Science 359, 920-926.

Wang, B., Jakus, A. E., Baptista, P. M., Soker, S., Soto-Gutierrez, A., Abecassis, M. M., et al. (2016). Functional maturation of induced pluripotent stem cell hepatocytes in extracellular matrix - a comparative analysis of bioartificial liver microenvironments. Stem Cells Transl. Med. 5, 1257-1267. doi: 10.5966/sctm. 2015-0235

Wang, H., Calvisi, D. F., and Chen, X. (2021). Organoids for the study of liver cancer. Semin. Liver Dis. 41, 19-27. doi: 10.1055/s-0040-1719176

Wang, K., Guzman, A. K., Yan, Z., Zhang, S., Hu, M. Y., Hamaneh, M. B., et al. (2019). Ultra-high-frequency reprogramming of individual long-term hematopoietic stem cells yields low somatic variant induced pluripotent stem cells. Cell Rep. 26, 2580-2592. E2587. doi: 10.1016/j.celrep.2019.02.021

Wang, S., Wang, X., Tan, Z., Su, Y., Liu, J., Chang, M., et al. (2019). Human ESCderived expandable hepatic organoids enable therapeutic liver repopulation and pathophysiological modeling of alcoholic liver injury. Cell Res. 29, 1009-1026. doi: 10.1038/s41422-019-0242-8

Wang, Y., Cui, C. B., Yamauchi, M., Miguez, P., Roach, M., Malavarca, R., et al. (2011). Lineage restriction of human hepatic stem cells to mature fates is made efficient by tissue-specific biomatrix scaffolds. Hepatology 53, 293-305. doi: 10.1002/hep. 24012

Watson, C. L., Mahe, M. M., Múnera, J., Howell, J. C., Sundaram, N., Poling, H. M., et al. (2014). An in vivo model of human small intestine using pluripotent stem cells. Nat. Med. 20, 1310-1314. doi: 10.1038/nm.3737

Weiss, M. J., Ray, K., Henthorn, P. S., Lamb, B., Kadesch, T., and Harris, H. (1988). Structure of the human liver/bone/kidney alkaline phosphatase gene. J. Biol. Chem. 263, 12002-12010.

Wörsdörfer, P. I. T., Asahina, I., Sumita, Y., and Ergün, S. (2020). Do not keep it simple: recent advances in the generation of complex organoids. J. Neural Transm. (Vienna) 127, 1569-1577. doi: 10.1007/s00702-020-02198-8

Wu, F., Wu, D., Ren, Y., Huang, Y., Feng, B., Zhao, N., et al. (2019). Generation of hepatobiliary organoids from human induced pluripotent stem cells. J. Hepatol. $70,1145-1158$.

Wu, X., Robotham, J. M., Lee, E., Dalton, S., Kneteman, N. M., Gilbert, D. M., et al. (2012). Productive hepatitis C virus infection of stem cell-derived hepatocytes reveals a critical transition to viral permissiveness during differentiation. PLoS Pathog. 8:e1002617. doi: 10.1371/journal.ppat.1002617

Xu, H., Wang, B., Ono, M., Kagita, A., Fujii, K., Sasakawa, N., et al. (2019). Targeted disruption of HLA genes via CRISPR-Cas9 generates iPSCs with enhanced immune compatibility. Cell Stem Cell 24, 566-578 e567. doi: 10.1016/j.stem. 2019.02.005

Xu, J., and Zeger, S. L. (2001). The evaluation of multiple surrogate endpoints. Biometrics 57, 81-87.

Yan, H., Zhong, G., Xu, G., He, W., Jing, Z., Gao, Z., et al. (2012). Sodium taurocholate cotransporting polypeptide is a functional receptor for human hepatitis B and D virus. elife 1:e00049.

Ye, S., Boeter, J. W., Mihajlovic, M., van Steenbeek, F. G., van Wolferen, M. E., Oosterhoff, L. A., et al. (2020). A chemically defined hydrogel for human liver organoid culture. Adv. Funct. Mater. 30:2000893.

Yin, X., Mead, B. E., Safaee, H., Langer, R., Karp, J. M., and Levy, O. (2016). Engineering stem cell organoids. Cell Stem Cell 18, 25-38. doi: 10.1016/j.stem. 2015.12.005

Yu, J., Vodyanik, M. A., Smuga-Otto, K., Antosiewicz-Bourget, J., Frane, J. L., Tian, S., et al. (2007). Induced pluripotent stem cell lines derived from human somatic cells. Science 318, 1917-1920.

Zahmatkesh, E., Ghanian, M. H., Zarkesh, I., Farzaneh, Z., Halvaei, M., Heydari, Z., et al. (2021). Tissue-specific microparticles improve organoid microenvironment for efficient maturation of pluripotent stem-cell-derived hepatocytes. Cells 10:1274. doi: 10.3390/cells10061274

Zhang, M., Sun, P., Wang, Y., Chen, J., Lv, L., Wei, W., et al. (2015). Generation of self-renewing hepatoblasts from human embryonic stem cells by chemical approaches. Stem Cells Transl. Med. 4, 1275-1282. doi: 10.5966/sctm.20150051

Zhao, T., Zhang, Z.-N., Westenskow, P. D., Todorova, D., Hu, Z., Lin, T., et al. (2015). Humanized mice reveal differential immunogenicity of cells derived from autologous induced pluripotent stem cells. Cell Stem Cell 17, 353-359. doi: 10.1016/j.stem.2015.07.021

Zhu, M., Huang, Y., Bian, S., Song, Q., Zhang, J., Zheng, W., et al. (2020). Organoid: current implications and pharmaceutical applications in liver diseases. Curr. Mol. Pharmacol. doi: 10.2174/1874467213666201217115854

Conflict of Interest: The authors declare that the research was conducted in the absence of any commercial or financial relationships that could be construed as a potential conflict of interest.

Publisher's Note: All claims expressed in this article are solely those of the authors and do not necessarily represent those of their affiliated organizations, or those of the publisher, the editors and the reviewers. Any product that may be evaluated in this article, or claim that may be made by its manufacturer, is not guaranteed or endorsed by the publisher.

Copyright (c) 2021 Chang, Bogacheva and Lou. This is an open-access article distributed under the terms of the Creative Commons Attribution License (CC BY). The use, distribution or reproduction in other forums is permitted, provided the original author(s) and the copyright owner(s) are credited and that the original publication in this journal is cited, in accordance with accepted academic practice. No use, distribution or reproduction is permitted which does not comply with these terms. 